\title{
Clastic Dikes of Heart Mountain Fault Breccia, Northwestern Wyoming, and Their Significance
}

GEOLOGICAL SURVEY PROFESIONAL PAPER 1133
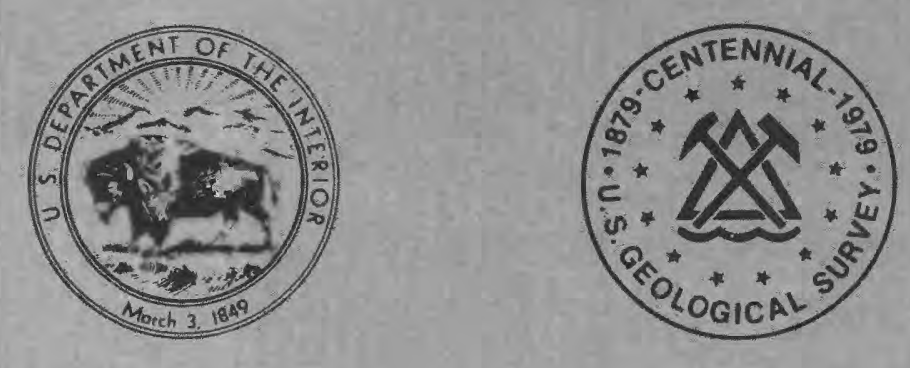


\section{Clastic Dikes of Heart Mountain Fault Breccia, Northwestern Wyoming, and Their Significance}

By WILLIAM G. PIERCE

GEOLOGICAL SURVEY PROFESSIONAL PAPER 1133

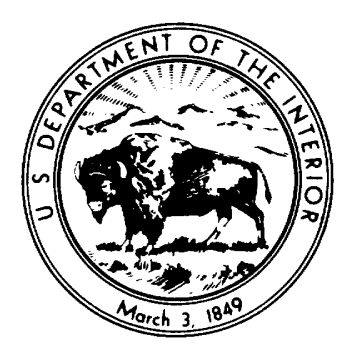

\begin{tabular}{lllllll}
\hline UNITED & StATES & GOVERNMENT & PRINTING & OFFICE, _ WASHington & : & 1979
\end{tabular} 


\title{
UNITED STATES DEPARTMENT OF THE INTERIOR
}

\author{
CECIL D. ANDRUS, Secretary
}

\section{GEOLOGICAL SURVEY}

H. William Menard, Director

\footnotetext{
Library of Congress Cataloging in Publication Data

Pierce, William Gamewell, 1904-

Clastic dikes of Heart Mountain fault breccia, northwestern Wyoming, and their significance.

(Geological Survey professional paper ; 1133)

Includes bibliographical references.

Supt. of Docs. no.: I 19.16:1133

1. Dikes (Geology)-Wyoming-Heart Mountain. 2. Breccia-WyomingHeart Mountain. I. Title. II. Series: United States. Geological Survey. Professional paper : 1133.

$\begin{array}{lll}\text { QE611.5U6P53 79-607991 } & \end{array}$
}

For sale by the Superintendent of Documents, U.S. Government Printing Office Washington, D.C. 20402

Stock Number 024-001-03252-0 


\section{CONTENTS}

Abstract

Introduction

General features of the Heart Mountain fault

Clastic dikes of fault breccia

General features of clastic dikes in upper-plate

carbonate rocks

General features of clastic dikes in volcanic rocks

Description of dikes at specific sites

Area 1, south of Silver Gate, Mont.

Calcibreccia dikes in Paleozoic rocks of

the upper plate

Calcibreccia dikes in the Wapiti Formation .......... 6

Area 2, southeast of Silver Gate, Mont.
Description of dikes at specific sites-Continued

Area 3, north of Republic Mountain -

Area 4, south of Pilot Creek _._._._.

Area 5, north of Jim Smith Peak

Area 6, near White Mountain _....................... 17

Area 7, west of Trout Creek

Other sites of clastic dikes

Breccia and brecciation produced by the Heart Mountain fault _ 20

Mechanism of dike injection _._.

Geologic significance of the clastic dikes _.................... 23

Summary

Acknowledgments - -

References cited

\section{ILLUSTRATIONS}

Figure 1. Map showing location of four phases of Heart Mountain fault and sites of clastic dikes of fault breccia

2. Photograph of calcibreccia dikes in the Three Forks Formation, area 1

3. Cross section in area 1 showing calcibreccia dikes in blocks of the upper plate and in the Wapiti Formation

4-8. Photographs from area 1 showing:

4. Calcibreccia dike with three components

5. Specimen of calcibreccia dike containing carbonized wood

6. Calcibreccia dike containing carbonized wood _.

7. Irregular borders between calcibreccia dikes and enclosing dikelike body of the Wapiti Formation

8. Calcibreccia dike containing xenoliths of Precambrian rocks

9. Cross section in area 1 showing movement of fault breccia and basal part of the Wapiti Formation into dikes

10. Cross section in area 2 showing relation of calcibreccia to Heart Mountain fault, surface of tectonic denudation, and the Wapiti Formation.....

11-22. Photographs showing:

11. Polished specimen of plume of Wapiti Formation extending into calcibreccia dike, area 2

12. Upper end of calcibreccia dike, area 2

13. Antiform of calcibreccia, area 2

14. Calcibreccia dike intermixed on its borders with the Wapiti Formation, area 3

15. Heart Mountain fault breccia overlain by the Wapiti Formation, area 4

16. Polished specimen of upper third of Heart Mountain fault breccia, area 4

17. Mound of Heart Mountain fault breccia, area 4

18. Polished specimen of calcibreccia from mound, area 4

19. Polished specimen of calcibreccia dike in lower part of the Wapiti Formation, area 4

20. Flat-lying calcibreccia dike, area 4 .

21. Polished specimen of calcibreccia interlayered with basal part of the Wapiti Formation, area 5

22. Irregular layer of calcibreccia in basal part of the Wapiti Formation, area 5

23. Cross section in area 7 showing relation of a dike of the Wapiti Formation containing stringers of calcibreccia to wallrock of Madison Limestone and Wapiti Formation _.

24. Photograph of dike of volcanic breccia of the Wapiti Formation containing calcibreccia in contact with fault block of Madison Limestone, area 7 .

25. Photographs showing polished specimens of calcibreccia from dike of volcanic rock of the Wapiti Formation, area 7 - 19

26. Cross section in area 3 showing degrees of deformation in brecciated limestone mass above Heart Mountain fault _.._22

27. Photograph showing polished specimen of brecciated limestone, area 3 
TABLE

TABLE 1. Location of and brief data on other calcibreccia dikes 


\title{
CLASTIC DIKES OF HEART MOUNTAIN FAULT BRECCIA, NORTHWESTERN WYOMING, AND THEIR SIGNIFICANCE
}

\author{
By William G. Pierce
}

\begin{abstract}
Structural features in northwestern Wyoming indicate that the Heart Mountain fault movement was an extremely rapid, cataclysmic event that created a large volume of carbonate fault breccia derived entirely from the lower part of the upper plate. After fault movement had ceased, much of the carbonate fault breccia, here called calcibreccia, lay loose on the resulting surface of tectonic denudation. Before this unconsolidated calcibreccia could be removed by erosion, it was buried beneath a cover of Tertiary volcanic rocks: the Wapiti Formation, composed of volcanic breccia, poorly sorted volcanic breccia mudflows, and lava flows, and clearly shown in many places by interlensing and intermixing of the calcibreccia with basal volcanic rocks. As the weight of volcanic overburden increased, the unstable water-saturated calcibreccia became mobile and semifluid and was injected upward as dikes into the overlying volcanic rocks and to a lesser extent into rocks of the upper plate. In some places the lowermost part of the volcanic overburden appears to have flowed with the calcibreccia to form dikelike bodies of mixed volcanic rock and calcibreccia. One calcibreccia dike even contains carbonized wood, presumably incorporated into unconsolidated calcibreccia on the surface of tectonic denudation and covered by volcanic rocks before moving upward with the dike. Angular xenoliths of Precambrian rocks, enclosed in another calcibreccia dike and in an adjoining dikelike mass of volcanic rock as well, are believed to have been torn from the walls of a vent and incorporated into the basal part of the Wapiti Formation overlying the clastic carbonate rock on the fault surface. Subsequently, some of these xenoliths were incorporated into the calcibreccia during the process of dike intrusion.

Throughout the Heart Mountain fault area, the basal part of the upper-plate blocks or masses are brecciated, irrespective of the size of the blocks, more intensely at the base and in places extending upward for several tens of meters. North of Republic Mountain a small 25-m-high upper-plate mass, brecciated to some degree throughout, apparently moved some distance along the Heart Mountain fault as brecciated rock. Calcibreccia dikes intrude upward from the underlying $2 \mathrm{~m}$ of fault breccia into the lower part of the mass and also from its top into the overlying volcanic rocks; an earthquake-related mechanism most likely accounts for the observed features of this deformed body.

Calcibreccia dikes are more common within the bedding-plane phase of the Heart Mountain fault but also occur in its transgressive and former land-surface phases. Evidence that the Wapiti Formation almost immediately buried loose, unconsolidated fault breccia that was the source of the dike rock strongly suggests a rapid volcanic deposition over the area in which clastic dikes occur, which is at least $75 \mathrm{~km}$ long.

Clastic dikes were injected into both the upper-plate and the volcanic rocks at about the same time, after movement on the Heart Mountain fault had ceased, and therefore do not indicate a fluidflotation mechanism for the Heart Mountain fault.

The difference between contacts of the clastic dikes with both indurated and unconsolidated country rock is useful in field mapping
\end{abstract}

at localities where it is difficult to distinguish between volcanic rocks of the Cathedral Cliffs and Lamar River Formations, and the Wapiti Formation. Thus, calcibreccia dikes in the Cathedral Cliffs and Lamar River Formations show a sharp contact because the country rock solidified prior to fault movement, whereas calcibreccia dikes in the Wapiti Formation in many instances show a transitional or semifluid contact because the country rock was still unconsolidated or semifluid at the time of dike injection.

\section{INTRODUCTION}

General features of the Heart Mountain fault have been described by Dake (1918), Hewett (1920), Bucher (1933, 1940), Pierce (1941, 1957,1960), Voight (1974), and Prostka (1978); detailed mapping of the fault and of the areal extent of the upper plate have been published (see fig. 1 for references). In this report attention will be focused upon clastic dikes of the Heart Mountain fault breccia, which furnish striking and unusual evidence on the brief lapse of time involved in the Heart Mountain fault emplacement process and provide some clues on the probable mechanism of both fault movement and dike injection.

Four major points will be developed in this report. (1) The calcibreccia dikes intruded two quite different kinds of country rock-Paleozoic carbonate and Tertiary volcanic rocks-but apparently were injected at essentially the same time and show a common mechanism, namely, lithostatic pressure due to burial by a rapidly accumulating cover of volcanic rocks, the Wapiti Formation. (2) The dikes are an aid in distinguishing fault-emplaced from nonfault-emplaced volcanic rocks. (3) Their wide distribution indicates that at least the lower part of the Wapiti Formation was rapidly deposited over a large area. (4) The dikes confirm an earlier conclusion (Pierce, 1968, 1973b) that the Heart Mountain fault movement was a cataclysmic event and cast further doubt on some of the mechanisms proposed for this fault movement.

In the course of their preparation of a geologic map of the Pilot Peak quadrangle, Wyoming, Pierce, Nelson, and Prostka (1973) differed as to whether the Heart Mountain fault movement had occurred during or after deposition of the Lamar River Formation, a name pro- 


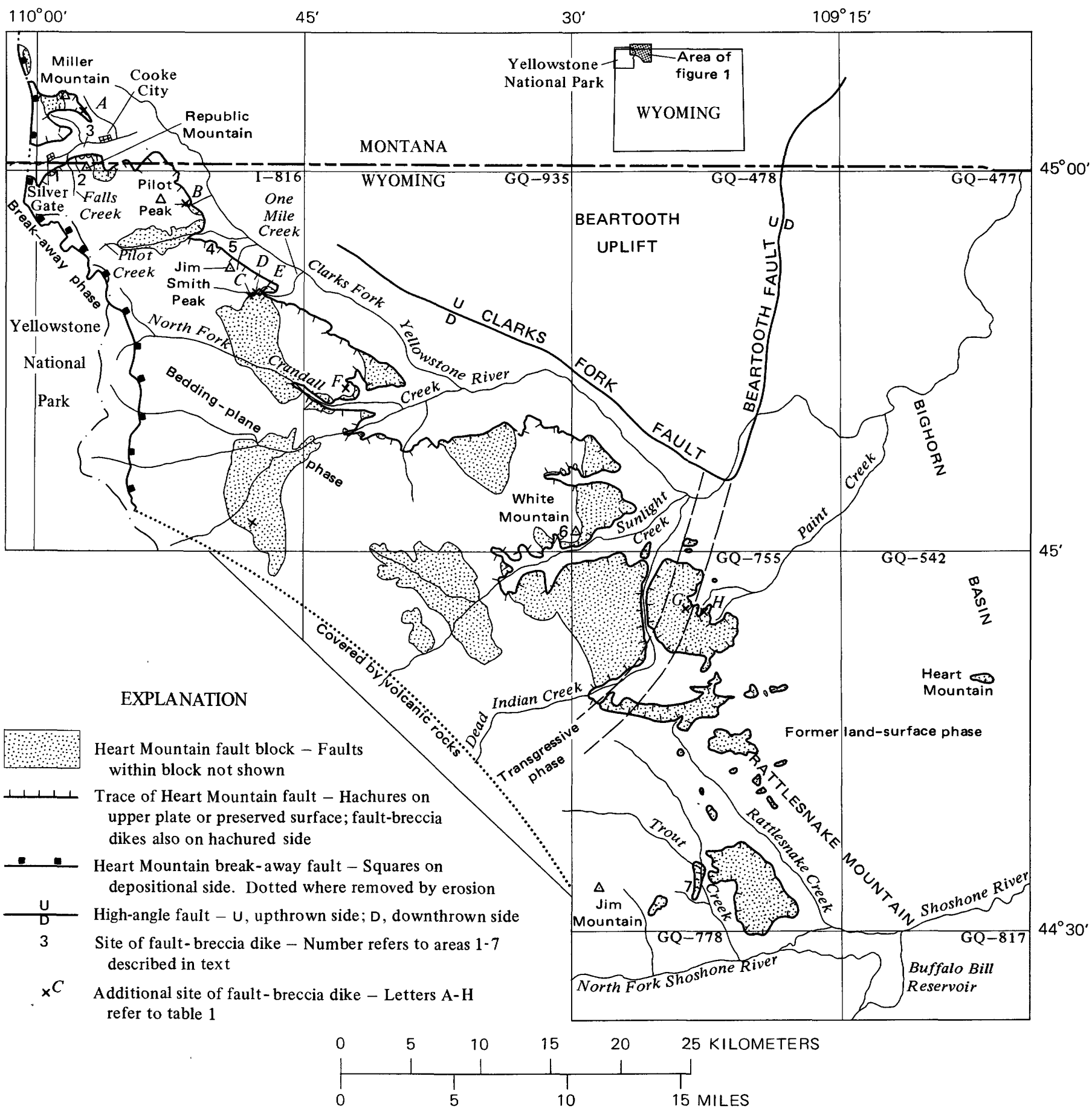

Figure 1.-Map showing location of four phases of Heart Mountain fault and sites where clastic dikes of fault breccia are found. For geologic setting and detailed location of calcibreccia dikes in northwestern part of area, see Pierce, Nelson, and Prostka (1973). GQ numbers refer to Geologic Quadrangle Maps and I number to Miscellaneous Investigations Series Map published by U.S. Geological Survey at a scale of $1: 62,500$.

posed by Smedes and Prostka (1972) for the lowest volcanic rocks of northeastern Yellowstone National Park including all rocks of the Cathedral Cliffs Formation (Pierce, 1963a). These differences remained unresolved at the time of publication, and so areas with alternate interpretation were designated accordingly on the map. Subsequent studies of the Heart Mountain fault, fault breccia, and clàstic dikes (for example, areas 1-3 and 4-5, fig. 1, which Prostka (1978, p. 428) interpreted as sites of fault-emplaced volcanic rocks) have shown that the volcanic rocks are depositional over the Heart Mountain fault surface of tectonic denudation. 
On their map, Pierce, Nelson, and Prostka designated the volcanic rocks in areas 1-3 (fig. 1) as the Lamar River and Cathedral Cliffs Formations, undivided; this assignment is unsatisfactory because the Cathedral Cliffs Formation is part of the upper plate and thus is older than the Heart Mountain fault, and the Lamar River Formation in its type area (Smedes and Prostka, 1972) in the Abiathar Peak quadrangle (Prostka and others, 1975) also predates the faulting. In view of the difficulty in distinguishing between the Lamar River and Wapiti Formations east of the Heart Mountain breakaway fault, it is suggested that the Lamar River Formation be discontinued in the area of the Heart Mountain fault and that the Cathedral Cliffs Formation be used for the pre-Wapiti volcanic rocks.

\section{GENERAL FEATURES OF THE HEART MOUNTAIN FAULT}

The Heart Mountain fault is in northwestern Wyoming, between the northeast corner of Yellowstone National Park and the west flank of the Bighorn Basin. Near the close of the early Eocene Epoch, rocks in a $1,300-\mathrm{km}^{2}$ area between the breakaway and transgressive phases of the Heart Mountain fault (fig. 1) became detached along a bedding plane and moved southeast. During movement, the upper plate broke into more than 50 blocks, ranging from a few tens of meters to $8 \mathrm{~km}$ across, scattered over an area of 3,400 $\mathrm{km}^{2}$ that stretched $105 \mathrm{~km}$ in a northwest-southeast direction. Horizontal movement of the most southeasterly blocks was $50 \mathrm{~km}$; to the northwest, the extent of movement diminished progressively toward the breakaway fault. The overall slope of the fault, which can be determined fairly closely, was less than $2^{\circ}$.

The upper plate of the Heart Mountain fault is composed of about $500 \mathrm{~m}$ of predominantly carbonate rocks of the Bighorn Dolomite (Ordovician), the Jefferson and Three Forks Formations (Devonian), and the Madison Group (Mississippian); and of from 0 to $600 \mathrm{~m}$ of volcanic rocks of the Cathedral Cliffs and Lamar River Formations (Eocene). The detachment horizon is underlain by $360 \mathrm{~m}$ of Cambrian shale and limestone of the Snowy Range, Pilgrim, and Gros Ventre Formations, and by the Flathead Sandstone, which rests unconformably on Precambrian granitic rocks.

The distribution of the Crandall Conglomerate, an unusual stream-channel deposit (Pierce, 1973a), indicates a preliminary southeastward movement in the northeastern part of the Heart Mountain fault mass that opened a deep rift about $1 \mathrm{~km}$ wide through the upper plate. Erosion then cut a channel as deep as 100 $\mathrm{m}$ into the underlying Cambrian shale, in which $150 \mathrm{~m}$ or more of this coarse conglomerate was subsequently deposited. This preliminary movement was followed in rapid succession by the Reef Creek detachment fault (Pierce, 1963b) and then by a main movement of the entire upper plate that left the lower part of the conglomerate in place but carried the upper part, along with rocks of the upper plate, roughly $24 \mathrm{~km}$ southeastward.

\section{CLASTIC DIKES OF FAULT BRECCIA}

The clastic dikes of carbonate fault breccia were first described by Pierce (1968) as limestone dikes at 6 general sites; since then, the number of sites has been increased to 15 . These dikes are composed of finely crushed dolomite and limestone in a matrix of carbonate flour, firmly cemented by calcium carbonate to form a resistant rock that breaks with conchoidal fracture. For brevity the term "calcibreccia dike" will be used here in place of the longer "clastic calcium and magnesium carbonate breccia dike"; the term "calcibreccia" will be used at times to refer to the Heart Mountain fault breccia either as tectonic breccia or as dike rock. The source of carbonate fault breccia or calcibreccia was the clastic rock formed by movement of the upper plate of the Heart Mountain fault.

The Heart Mountain fault breccia is a cataclastic rock (cataclasite) composed of angular carbonate clasts in a microbreccia of smaller fragments without primary cohesion. The fault breccia is not mylonite, even in a broad sense, nor does it have fluxion structure; it is not only found on the fault surface beneath the large blocks of Paleozoic rock composing the upper plate, but also is irregularly distributed on the surface of tectonic denudation between these blocks. A few calcibreccia dikes are seen in Paleozoic rocks that form remnants of the upper plate, but most are found in the volcanic rocks deposited on the surface of tectonic denudation. The dikes are believed to have intruded both upperplate and volcanic rocks at essentially the same time, soon after deposition of the first postfault volcanic rocks.

The associated volcanic rocks in which clastic dikes occur, originally informally known as the early basic breccia of Hague (1899), were subsequently named the Wapiti Formation by Nelson and Pierce (1968). In the Pilot Peak quadrangle map (Pierce and others, 1973), the volcanic rocks containing clastic dikes were called the Lamar River and Cathedral Cliffs Formations, undivided. However, inasmuch as throughout a much larger area of the Heart Mountain fault the volcanic rocks that were deposited on the surface of tectonic denudation are unquestionably included in the Wapiti Formation, that designation will be followed here, es- 
pecially because the surface of tectonic denudation permits a precise time correlation between units.

Features of the Heart Mountain fault breccia clearly indicate that it is the source material for the calcibreccia dikes in both the upper-plate blocks of Paleozoic rocks and in the volcanic rocks. The lower parts of many blocks of the upper plate are intensely brecciated, and so the dike rock that they enclose was evidently derived from fault breccia. However, most of the volcanic rocks containing calcibreccia dikes are not from the upper plate, nor were they fault emplaced. They are postfaulting in age, as shown by: (1) the absence of clasts of volcanic rocks in the fault breccia, in contrast to the abundance of carbonate fault breccia; (2) the semifluid mixing of calcibreccia with volcanic rock (figs. 21, 22); and (3) their depositional relation against and over Heart Mountain fault masses of all sizes (figs. 3, 26). Consequently, the only possible source for the calcibreccia in the dikes in volcanic rocks also was the Heart Mountain fault breccia. Some geologic features indicating that the dikes in both the upper-plate and volcanic rocks were in fact derived from Heart Mountain fault breccia are: (1) the fault breccia and dike rock are lithologically similar except for minor additions of wallrock to the dikes, (2) the dikes are most abundant in the basal part of the rocks resting on the Heart Mountain fault, (3) many dikes extend downward to the Heart Mountain fault but none are below it, and (4) the dikes pinch out upward and exhibit an upward-branching trend.

\section{GENERAL FEATURES OF CLASTIC DIKES IN UPPER-PLATE CARBONATE ROCKS}

Calcibreccia dikes in blocks of Paleozoic rock in the upper plate of the Heart Mountain fault have been observed at four sites (areas 1, 3, and 6 and locality $E$, fig. 1). These dikes were not formed by the movement of country rock along dike walls, because the adjoining rock is not brecciated and the dikes show abrupt changes in trend through the country rock. An example of this irregular trending is a 2- to 5-cm-wide calcibreccia dike in thin-bedded shale of the Three Forks Formation in area 1 (fig. 2).

Although numerous faults have been observed and mapped in Paleozoic rocks of the upper plate, none have been found that contain calcibreccia. The calcibreccia dikes observed in upper-plate Paleozoic rocks die out upward and can be traced downward to the Heart Mountain fault or, in most instances, to concealed areas within $1 \mathrm{~m}$ or so of the fault. Therefore, these dikes, which are composed of fault breccia, were evidently injected upward along fractures in the upper plate.

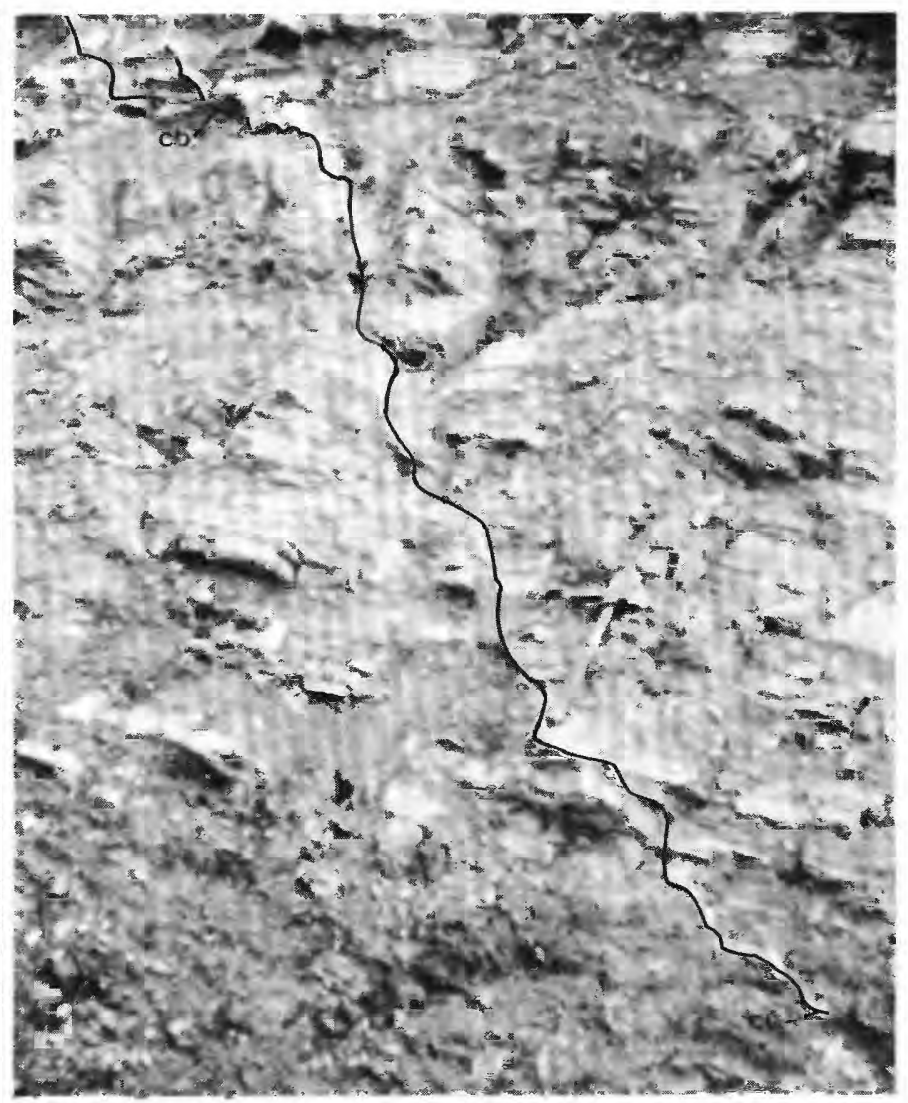

FIGURE 2.-Calcibreccia dike (cb) in steeply inclined thin-bedded shale of the Three Forks Formation in upper plate of the Heart Mountain fault in area 1, south of Silver Gate, Mont. (see fig. 3 for location). Dike is as much as $5 \mathrm{~cm}$ thick and pinches and swells as it alternately follows and cuts across bedding. End of hammer handle marks edge of dike.

\section{GENERAL FEATURES OF CLASTIC DIKES IN VOLCANIC ROCKS}

Calcibreccia dikes in volcanic rocks have been observed at 15 sites (areas 1-7 and localities $A-H$, fig. 1 ), nearly four times the number for those in the upper plate. This unequal distribution may be more apparent than real because (1) more of the Heart Mountain fault area is covered by the Wapiti Formation rather than by upper-plate rocks, and (2) calcibreccia dikes are more likely to be observed in the volcanic rocks because of the greater contrast between dikes and country rock.

The volcanic rocks in which calcibreccia dikes occur almost exclusively are in the lowermost part of the early or middle Eocene Wapiti Formation, which is composed of volcanic breccia and of poorly sorted andesitic volcaniclastic rocks and lava flows; the calcibreccia dikes are more commonly found in the volcanic breccia. Much of the trachyandesitic material in the breccia consists of volcanic detritus, either pyroclastic rock or fragments of preexisting solid volcanic rocks of 
the Wapiti Formation. The matrix of the breccia is fine grained and is composed dominantly of silt- to coarse sand-size detritus.

Although some calcibreccia dikes in the Wapiti Formation consist entirely of carbonate fault breccia, most contain scattered fragments of volcanic rock. A few dikes have a central core of calcibreccia with borders of volcanic dike rock (fig.6), or with borders of mixed calcibreccia and volcanic rock (fig. 8). One calcibreccia dike contains carbonized wood (fig. 5) and another, fragments of Precambrian granitic rock (fig. 8). Several dikes consist of volcanic breccia mixed with a minor to moderate amount of carbonate breccia; this breccia is referred to as a mixed breccia. The dikes usually range in thickness from a few centimeters to $0.5 \mathrm{~m}$; commonly they pinch and swell and are discontinuous, but some have a fairly uniform thickness over short distances. The calcibreccia also occurs as irregular bodies, lenses, and pods in the volcanic rocks (figs. 17, 21, and 22 ), and is irregularly distributed over or against small blocks of the upper plate (fig. 10); at one site (area 2, fig. 1), calcibreccia has flowed into a small antiform (fig. 13).

\section{DESCRIPTION OF DIKES AT SPECIFIC SITES}

Seven sites of dike occurrence to be discussed are numbered on the map (areas 1-7, fig. 1) : areas 1 to 3 are in the Silver Gate-Cooke City, Mont., area; areas 4 and 5 are $12 \mathrm{~km}$ and $14 \mathrm{~km}$ to the southeast, respectively; area 6 is near White Mountain, $32 \mathrm{~km}$ farther southeast; and area 7 is west of Trout Creek, 28 $\mathrm{km}$ still farther to the southeast. Eight additional sites of calcibreccia dikes are lettered (locs. $A-H$, fig. 1 ), and data on them are summarized in table 1.

Clastic dikes of fault breccia have not been described in detail in the geologic literature, so far as this author is aware, although fault gouge injected into cracks in the upper-plate rocks of the Muddy Mountain thrust, Nevada, have been noted (Stanley and Morse, 1974; Brock and Engelder, 1977). Their occurrence, however, in both upper-plate and volcanic rocks is most unusual if not unique. The exceptional circumstances associated with the dikes of Heart Mountain fault breccia and the collateral geologic information that they provide make it desirable to give a detailed account of a number of dikes, rather than merely a generalized description.

\section{AREA 1, SOUTH OF SILVER GATE, MONTANA}

The calcibreccia dikes in area 1, south of Silver Gate, Mont., are the most easily accessible and can be reached on foot by a 200-m climb up the steep mountain slope due south of the town. As indicated by figure 3 , a variety of calcibreccia dikes can be seen there, both in upper-plate Paleozoic rocks and in the Eocene Wapiti Formation composed of volcanic rocks.

\section{CAI.CIBRECCIA DIKES IN PALEOZOIC ROCKS OF THE UPPER PLATE}

On the far right of figure 3 is the previously mentioned calcibreccia dike in the Three Forks Formation, shown in figure 2. Left of center in figure 3 is a much smaller, highly deformed upper-plate block with calcibreccia dikes. There, a very small Heart Mountain

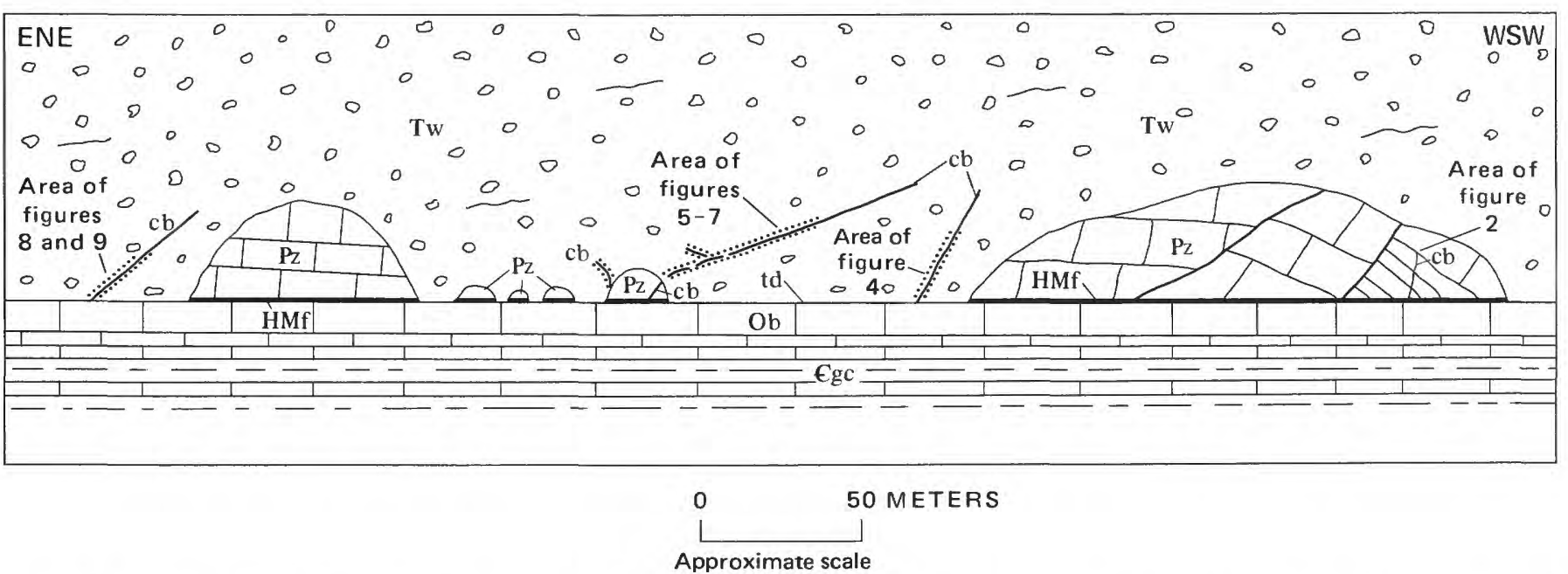

FIGURE 3.-Diagrammatic cross section of relations in area 1, south of Silver Gate, Mont., between calcibreccia dikes (cb) in Paleozoic rocks of the upper plate $(\mathrm{Pz})$ and in volcanic rocks of the Wapiti Formation (Tw). Dots indicate flow banding adjacent to dikes and intermixing of calcibreccia with volcanic rock. HMf, Heart Mountain fault; td, surface of tectonic denudation; Ob, basal bed of Bighorn Dolomite; €gc, Grove Creek Limestone Member of the Snowy Range Formation. Faults in Paleozoic rocks do not extend into the Wapiti Formation. Not to scale. 
fault block of the Three Forks Formation, about $6 \mathrm{~m}$ across and $5 \mathrm{~m}$ high, contains several small irregular dikes of calcibreccia; one, about $1.5 \mathrm{~m}$ long, is in the west side of the block. The Wapiti Formation overlies this fault block, extends down its sides, and rests on the Heart Mountain fault surface of tectonic denudation adjacent to the block. In the east side of the block is one dike composed mainly of carbonate rock and some scattered fragments of shale of the Three Forks Formation, but the presence of volcanic rock fragments indicates that this dike was injected after the adjoining volcanic rocks were deposited. Evidence does not suggest that the dike material moved down, because that would be very unlikely, considering that the dike is composed almost entirely of fault breccia from beneath the block and from the adjoining surface of tectonic denudation. Rather, it appears that the calcibreccia in the dike moved up, and as it did so, a lateral flow occurred, both of underlying calcibreccia and of calcibreccia mixed with some volcanic rock from the adjoining area. Such general lateral flow of calcibreccia toward the dikes, as shown in figure 9, seems implicit as a means of acquiring the required volume of dike-filling material.

Layering is well developed in the calcibreccia parallel to the dike walls and is due to the flow of material through the dike. Although debris conceals a $1.5-\mathrm{m}$ interval between the bottom of the dike and the Heart Mountain fault, the dike can be traced diagonally upward for $1.5 \mathrm{~m}$ to the edge of the fault block, where it terminates at the contact between the Three Forks Formation and a 1.5-m-wide dikelike body (not shown in fig. 3) that consists of mixed volcanic and carbonate breccia containing stringers and pod-shaped bodies of calcibreccia. Above and to the southwest, a carbonate dike in volcanic rocks of the Wapiti Formation penetrates this dikelike body for about $0.5 \mathrm{~m}$ before pinching out $1 \mathrm{~m}$ from the end of the calcibreccia dike intruding shale of the Three Forks Formation.

\section{CALCIBRECCIA DIKES IN THE WAPITI FORMATION}

The dikes in the Wapiti Formation indicated in figure 3 will be discussed beginning with the one slightly to the right of the center of the figure. This one, shown in figure 4 , is a lensing dike of calcibreccia and volcanic breccia about $25 \mathrm{~m}$ long, intruded into the Wapiti Formation. Rubble conceals a 7-m interval between the lowermost exposed part of the dike and the Heart Mountain fault. The dike strikes N. $30^{\circ}$ E., has an arcuate shape, and is near vertical. A short distance from the bottom of the exposed portion of the dike is a detached block of Madison Limestone in the upper plate of the Heart Mountain fault (see figs. 3, 4). The Wapiti Formation, which covers the limestone block,

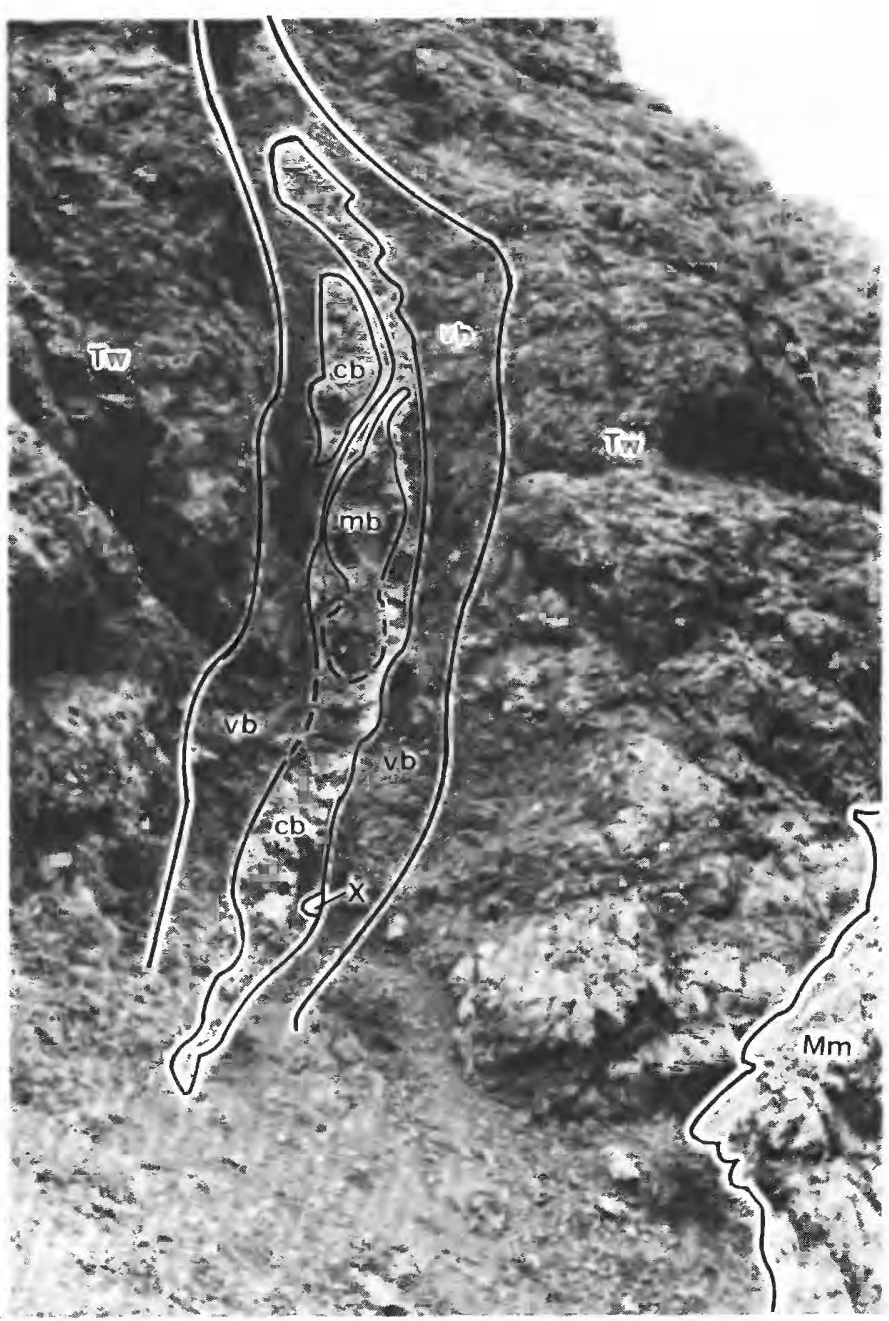

Figure 4.-Calcibreccia dike in area 1, south of Silver Gate, Mont., containing three components: calcibreccia (cb), volcanic breccia of the Wapiti Formation (vb), and mixed calcibreccia and volcanic breccia (mb) of the Wapiti Formation (Tw). The Madison Limestone $(\mathrm{Mm})$ is part of detached block of upper plate lying on Heart Mountain fault $6 \mathrm{~m}$ below view. " $x$ " indicates a $15-\mathrm{cm}$ limestone clast.

contains a few limestone fragments as much as $30 \mathrm{~m}$ across that were presumably picked up and incorporated into the Wapiti as it was deposited over the block.

The dike shown in figure 4 is made up of three components: calcibreccia, volcanic rocks of the Wapiti Formation, and a mixture of these two materials. In the central part of the dike is an irregular lenslike body of fine-grained calcibreccia containing scattered angular clasts of volcanic rock from less than 0.1 to 50 $\mathrm{cm}$ or more in diameter. The bulk of the fragments, however, are 1 to $2 \mathrm{~cm}$ across. Where the volcanic fragments are 1 to $2 \mathrm{~cm}$ in size, they constitute no more than 10 percent of the calcibreccia; where they are smaller, they appear to form a lesser proportion of the calcibreccia. Within the calcibreccia, in the central 
part of the dike, is an irregular mass of breccia about 2 $m$ long composed of about equal proportions of carbonate and volcanic rock fragments as much as $30 \mathrm{~cm}$ across. This breccia body is elongated roughly parallel to the walls of the dike. At one place in the lower part of the calcibreccia is a limestone clast $15 \mathrm{~cm}$ across (fig. 4). Volcanic breccia, much coarser than the calcibreccia, forms a zone 0.3 to $1 \mathrm{~m}$ wide on either side of the calcibreccia core and extends upward about $15 \mathrm{~m}$ above the core before pinching out. The volcanic breccia is intensely sheared and exhibits more or less vertically oriented, striated shear surfaces parallel to the dike walls. A specimen of the dike taken at the boundary between the calcibreccia and volcanic breccia, showing a very narrow transitional contact $1 \mathrm{~mm}$ or so thick between the two rock types, indicates that the volcanic breccia was unconsolidated to some degree at the time the calcibreccia was injected. Within the specimen, elongate grains and fragments of volcanic rock in both the calcibreccia and volcanic breccia show a preferential lengthwise orientation parallel to the dike walls.

About $25 \mathrm{~m}$ above and to the southeast of this dike, a similar, less prominent, thinner body of calcibreccia occurs within a moderately distinct dike of volcanic breccia. This dike, indicated on figure 3 by an arrow to the area of figures 5 through 7 , is about $120 \mathrm{~m}$ long, trends N. $55^{\circ}$ E., and contains fragments of volcanic rock. Calcibreccia within the dike of volcanic breccia pinches and swells, is discontinuous, and is locally absent, ranging from less than a few centimeters to $30 \mathrm{~cm}$ in width. At one place in the dike are two thin $(2-5 \mathrm{~cm})$ tabular bodies of calcibreccia $0.5 \mathrm{~m}$ apart.

In the summer of 1973 , while I was showing a group of visitors through this area, Charles Frye noticed a few small fragments of what appeared to be carbonized wood in one calcibreccia body in this dike; on further examination later in the summer, I identified definite particles of carbonized wood, some as much as $4 \mathrm{~cm}$ long (fig. 5), in calcibreccia in other parts of the dike. The wood occurs as numerous small pieces in a matrix of very fine grained carbonate breccia. Although fossil wood has been found in many places in the Wapiti Formation, the wood in this dike evidently was not secondarily derived from the volcanic rocks because it is entirely enclosed within calcibreccia and is free of associations to volcanic rock in the dike. Furthermore, the wood particles seem to have been incorporated into the calcibreccia after that breccia was formed because the wood is much too fragile to have withstood the deformation that produced the fault breccia. It is surprising that the wood has withstood the deformation accompanying its injection into the dike as well as it has, inasmuch as some of the wood, represented by very small specks in the calcibreccia, has thoroughly disin-

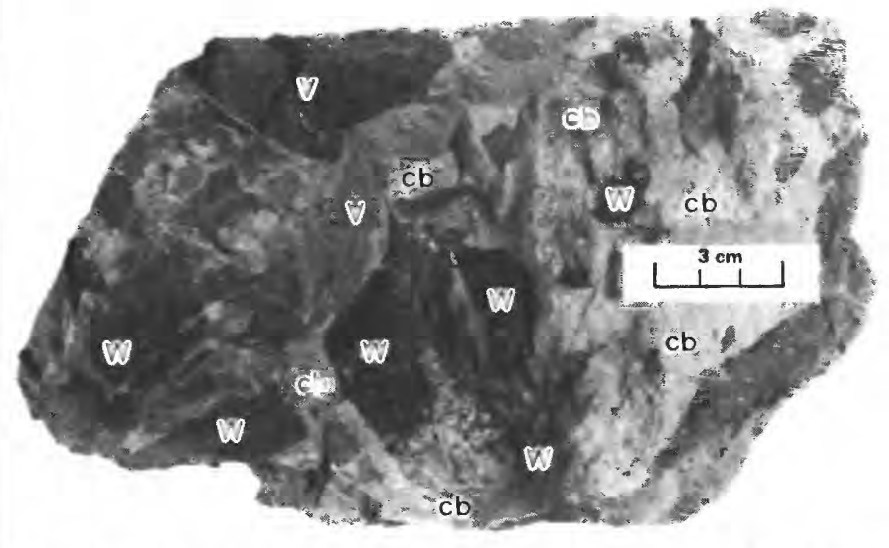

Figure 5-Specimen of calcibreccia dike in area 1, south of Silver Gate, Mont., containing fragments of carbonized wood (W) and a few fragments of volcanic rock ( $\mathrm{V}$ ) in a matrix of carbonate breccia (cb). Photograph by Lowell Kohnitz.

tegrated. The surface of tectonic denudation, created by movement along the Heart Mountain fault, was exposed for perhaps only a few hours or days after the fault movement ceased before being buried by volcanic rocks of the Wapiti Formation (Pierce, 1968). During this extremely brief interval, the carbonized wood became a constituent of the Heart Mountain fault breccia presumably by aerial or aqueous transport from a short distance away. The conditions that permitted inclusion of this wood into the Heart Mountain fault breccia probably were extremely rare because carbonized wood has been found only in this one dike. However, similar fossil wood, albeit much silicified and presumably from the same source as that in the calcibreccia, has also been noted in volcanic breccia of the dike near its northeast end.

The body of calcibreccia with the carbonized wood occurs within the seemingly flow banded volcanic breccia of the Wapiti Formation that constitutes the main mass of the dike (fig. 6). The bodies of volcanic breccia in the dike that borders the calcibreccia are about 10 $\mathrm{cm}$ wide, slightly darker than the adjoining wallrock, and contain a small amount of fine calcareous breccia. The core of calcibreccia at the southwest end of this dike lies about $25 \mathrm{~m}$ above the Heart Mountain fault, and the enclosing breccia of the Wapiti Formation pinches out a few meters higher up in the dike. At the northeast end of the dike, the discontinuous calcibreccia core can be traced down to within $3 \mathrm{~m}$ of the fault, below which it is concealed by talus. The contact between calcibreccia and volcanic breccia in the dike (fig. 7 ) is extremely irregular rather than planar, and the fragments in the calcibreccia do not show a preferred orientation parallel to the contact. Very thin stringers and protuberances of volcanic breccia into the calcibreccia indicate that the volcanic rock was in a some- 


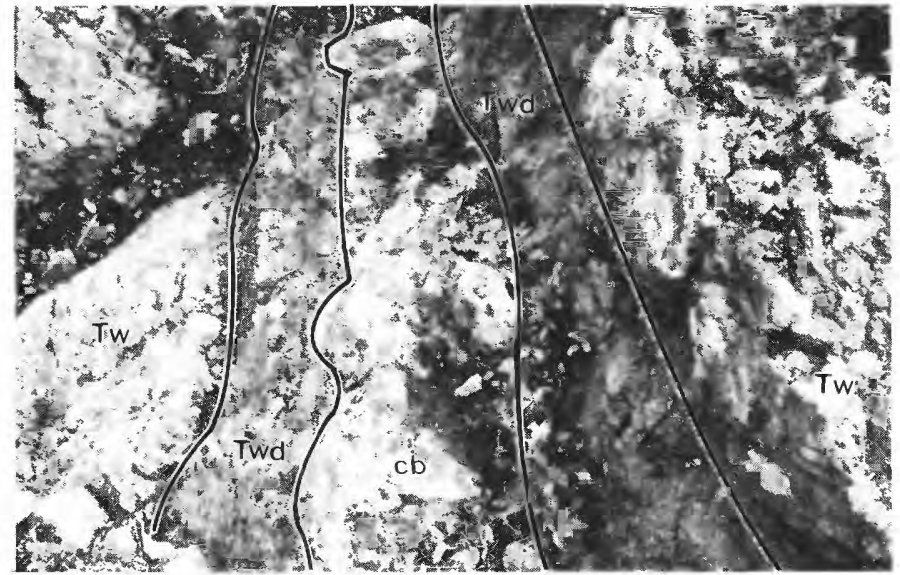

FiguRE 6.-Calcibreccia dike (cb) in area 1, south of Silver Gate, Mont., containing carbonized wood. The Wapiti Formation (Tw) seems to be flow banded (Twd) on both sides of calcibreccia dike.

what mobile state, that is, incompletely consolidated at the time of dike injection, and also that the fault movement which formed the calcibreccia preceded deposition of the Wapiti Formation.

One calcibreccia dike from a few to $45 \mathrm{~cm}$ wide (left, fig. 3), well exposed at the bottom and on the west side of a steep ravine, pinches and swells and is irregularly distributed within another, larger 1- to 2-m-wide dike of volcanic breccia of the Wapiti Formation that is sheared and has fairly well defined shear borders with the enclosing volcanic rock (fig. 8); the contact between the calcibreccia and intrusive volcanic breccia is gradational. The calcibreccia is predominantly carbonate rock but contains abundant fragments of volcanic rock. At the outer border of the calcibreccia is a 2-cm-wide zone of fine-grained rock composed of volcanic breccia intermixed with a small amount of calcibreccia. The contact of the mixed breccia with the calcibreccia and the outer contact with the volcanic breccia are both gradational through a thin zone.

In addition to this irregular but more or less continuous body of calcibreccia (fig. 8), other discontinuous stringers less than $1 \mathrm{~cm}$ to a few centimeters wide occur within the dike. The composite dike of volcanic breccia and calcibreccia is bordered by vertically sheared dikelike bodies of rock of the Wapiti Formation. The dikelike body on the south side (left, fig. 8) is about $3.5 \mathrm{~m}$ wide, with the outer half less sheared and its outer border less well defined than its inner border. The dikelike body of the Wapiti on the north side of the calcibreccia dike (right, fig. 8) is mostly covered, but the part that can be observed is similar to its counterpart on the south side of the dike.

An unusual feature of the dike shown in figure 8 is the occurrence of fragments of Precambrian granitic rock in the rocks that form the dike and in the dikelike

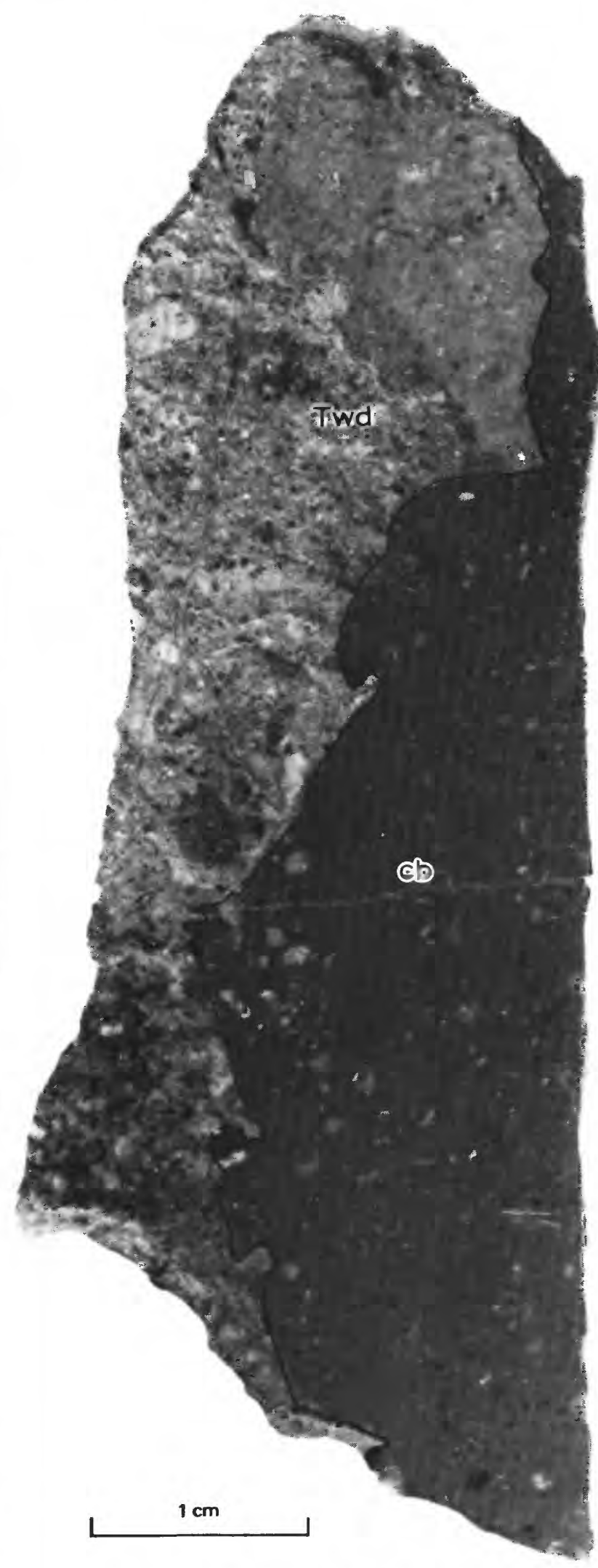

FiguRe 7.-Caption on facing page. 


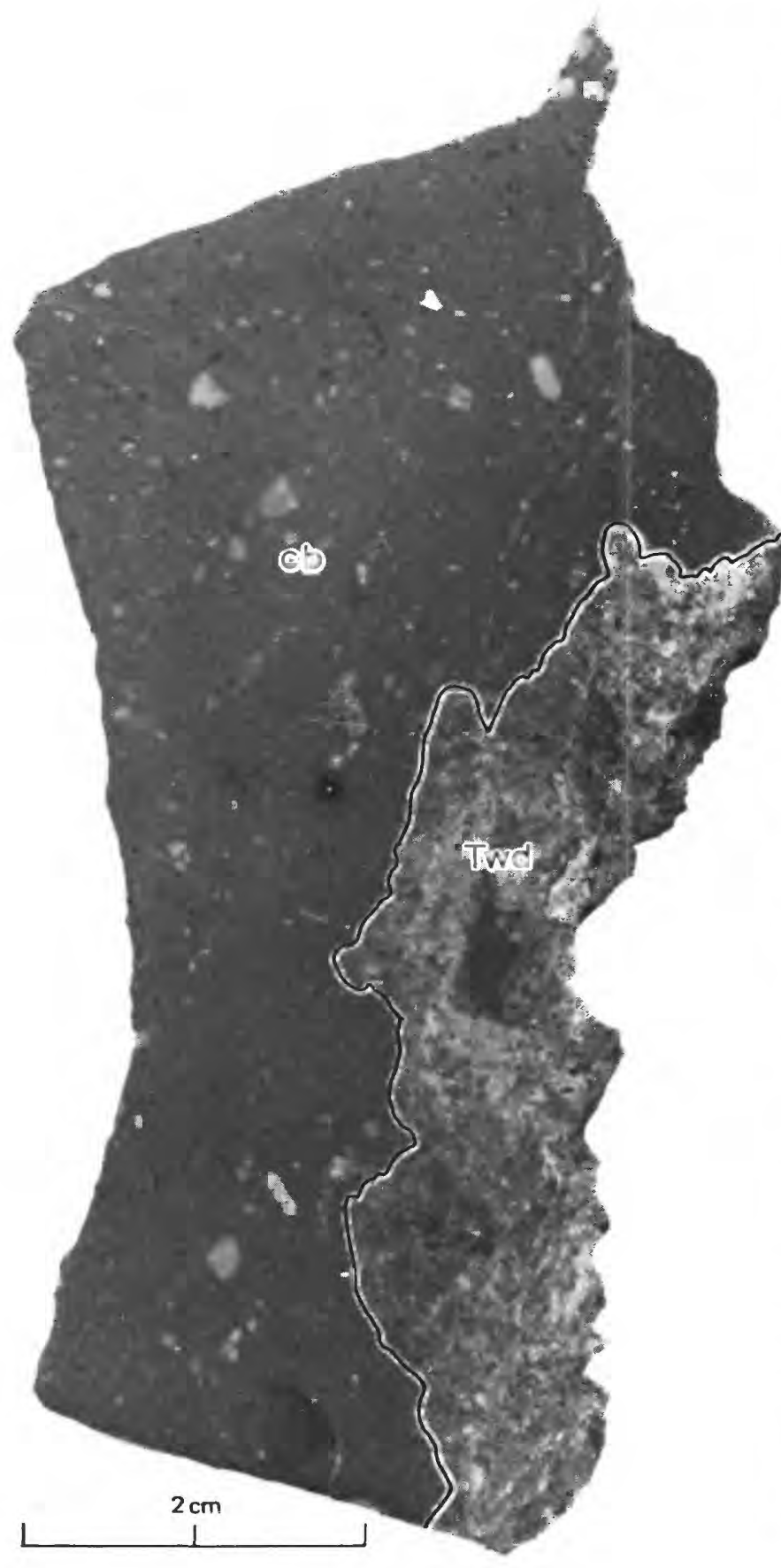

FIGURE 7.-Polished specimens of calcibreccia dike (cb) and adjoining dikelike body of the Wapiti Formation (Twd) in area 1, south of Silver Gate, Mont. Very thin stringers (not shown here) and protuberances of Wapiti Formation into calcibreccia indicate that country rock was incompletely consolidated at time calcibreccia dike of Heart Mountain fault breccia was injected into it. Photographs by Lowell Kohnitz.

bodies of sheared Wapiti volcanic breccia that border it. The xenoliths in the dike are angular and range from 1 or $2 \mathrm{~cm}$ across in the calcibreccia to $1 \mathrm{~m}$ across in

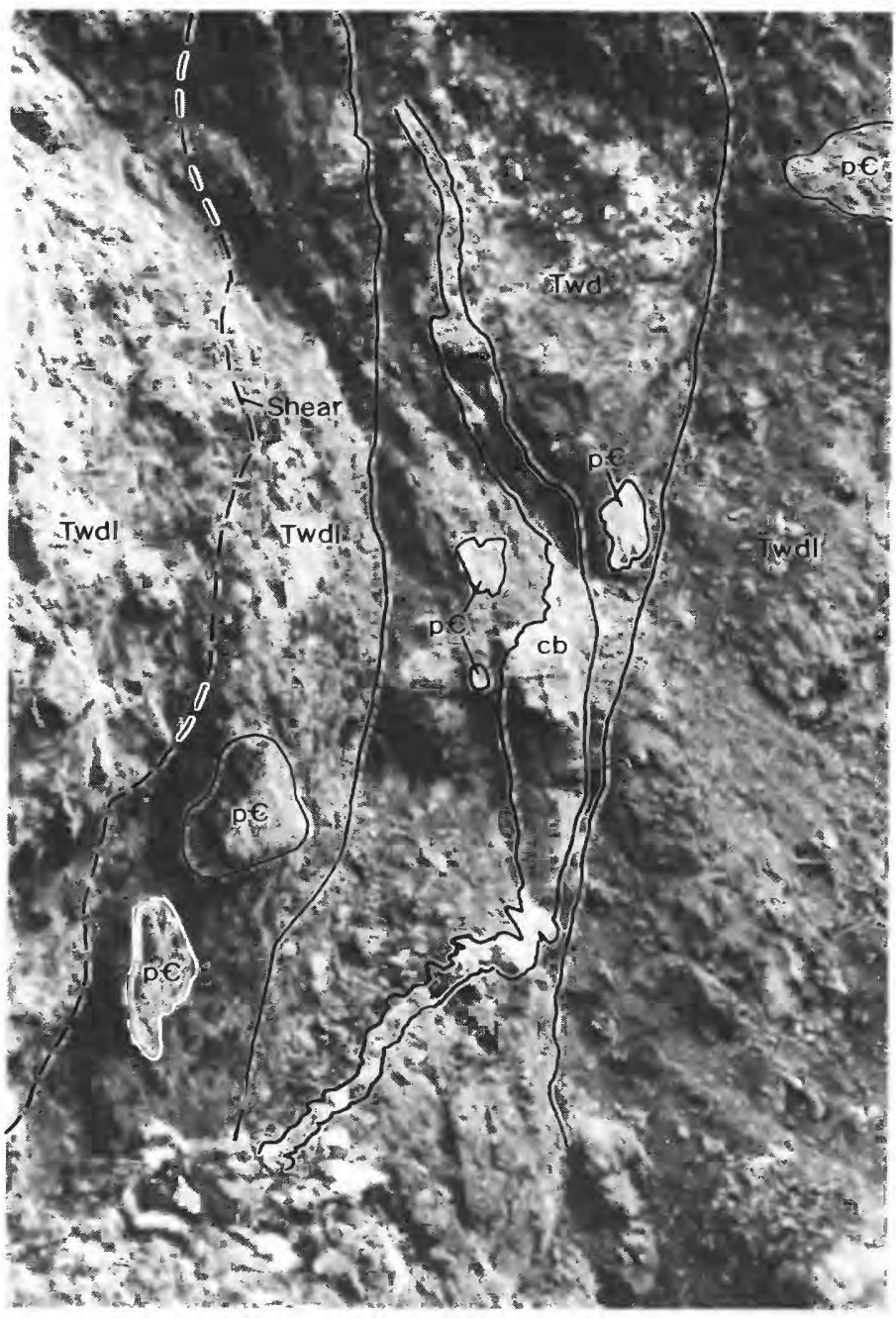

Figure 8.-Calcibreccia dike (cb) in area 1, south of Silver Gate, Mont., within and part of a dike of the Wapiti Formation (Twd). Calcibreccia dike and enclosing volcanic breccia both contain xenoliths of Precambrian rock (p€). The bordering, slightly less dikelike bodies of the Wapiti Formation (Twdl) also contain xenoliths of Precambrian rocks. None of the dikes extend beneath Heart Mountain fault ( $3 \mathrm{~m}$ below view shown).

the adjacent dikelike bodies of Wapiti breccia. The xenoliths occur in the lowest exposed parts of the dike and adjacent breccia, about $3 \mathrm{~m}$ above the Heart Mountain fault, and are scattered upward for $15 \mathrm{~m}$ in the dike and in the Wapiti that borders it. The Precambrian fragments in the vertically sheared Wapiti breccia occur close to the dike.

Inasmuch as the calcibreccia originally was irregularly distributed between the base of the Wapiti Formation and the surface of tectonic denudation, the calcibreccia must have flowed laterally and upward to form the dike, as illustrated in figure 9. Vertical striations and shears in the rocks of the Wapiti Formation that enclose the calcibreccia, as well as the relation 


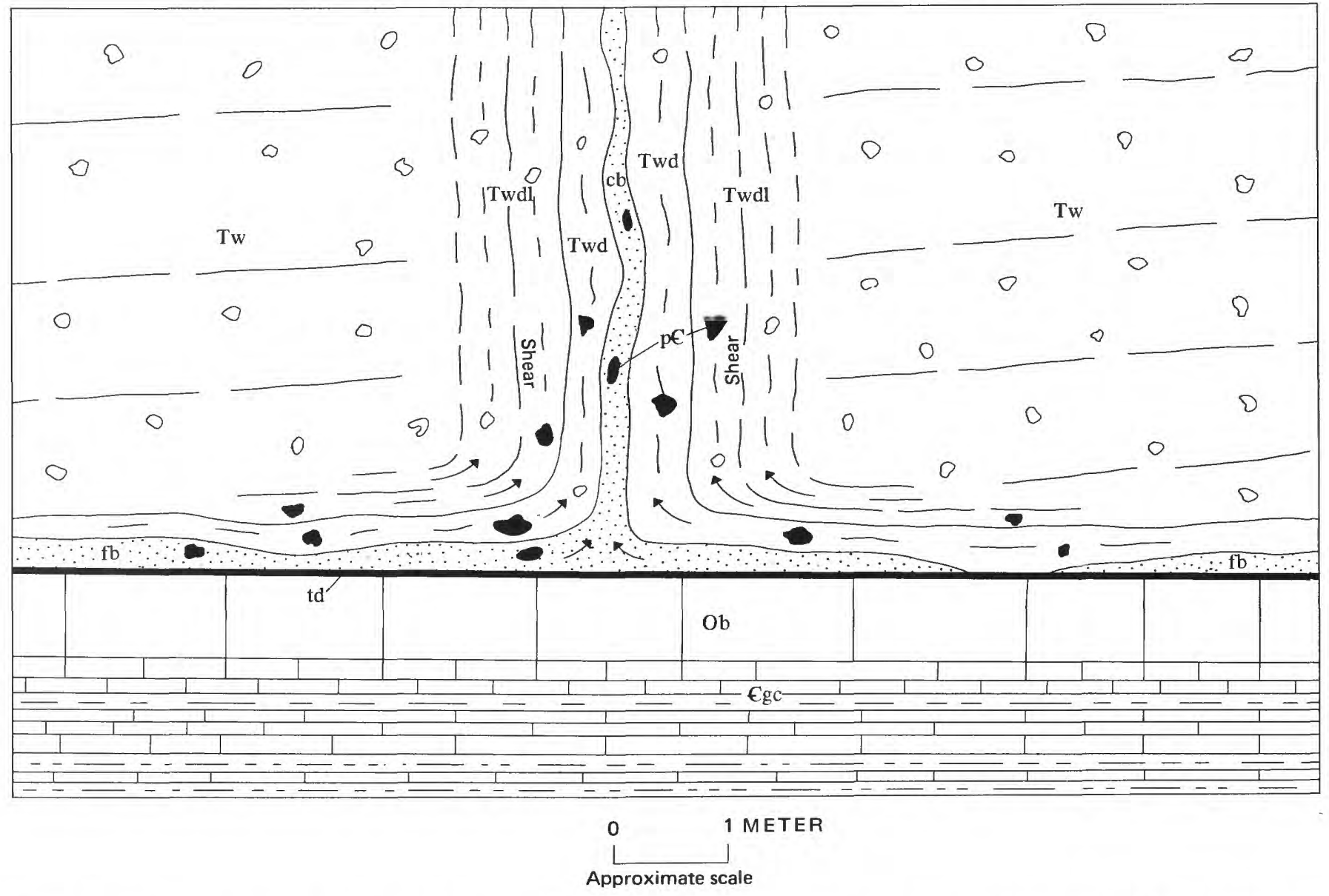

Figure 9.-Diagrammatic cross section of calcibreccia dike (cb) on left side of figure 3 in area 1, south of Silver Gate, Mont., showing its relation to the Heart Mountain fault carbonate breccia ( $\mathrm{fb}$ ), dike (Twd), dikelike (Twdl) bodies of Wapiti Formation, and bordering rocks of the Wapiti Formation (Tw). p€, angular xenoliths of Precambrian granitic rocks; Ob, basal bed of Bighorn Dolomite; €gc, Grove Creek Limestone Member of Snowy Range Formation; td, Heart Mountain fault surface of tectonic denudation. Arrows indicate direction of flow.

and mixing of the volcanic rock and calcibreccia, indicate that the Wapiti must have flowed with the carbonate fault breccia. The angularity of the granitic clasts, their wide range in size, and their lack of association with any sedimentary deposits seem to rule out any derivation by stream transport. A search was made for clasts of Precambrian rock in the basal part of the flat-lying Wapiti Formation but without success; however, about $100 \mathrm{~m}$ to the southwest, near the location of figure 4 shown on figure 3, crystalline clasts were found less than $1 \mathrm{~m}$ above the base but not higher up in the sequence. The basal volcanic rocks overlying a 25-m-high mass of deformed Devonian rocks in area 3 , north of Republic Mountain, also contain clasts of Precambrian rock. So far as is known, the Wapiti Formation never rests directly on Precambrian crystalline rocks, and Precambrian clasts have never been observed in the Heart Mountain fault breccia that is overlain by upper-plate rocks. Therefore, these clasts are interpreted to be xenoliths torn from the walls of a vent and incorporated into the basal part of the volcanic rocks immediately after the Heart Mountain fault movement.

\section{AREA 2, SOUTHEAST OF SILVER GATE, MONT.}

In area 2, southeast of Silver Gate, Mont., most of the calcibreccia dikes and related features are exposed on the east side of Falls Creek, and these features are described first. Here, the upper part of the Grove Creek Limestone Member of the Snowy Range Formation is well exposed on the east side of a steep $\mathrm{V}$-shaped valley and is overlain by 2 to $3 \mathrm{~m}$ of the basal bed of the Bighorn Dolomite. The top of this bed is the surface of tectonic denudation produced by movement on the Heart Mountain fault. Resting on this surface is (1) a small block of fault-transported Madison Limestone about $3 \mathrm{~m}$ high and (2) as much as $2 / 3 \mathrm{~m}$ of carbonate fault breccia and mixed carbonate and volcanic breccia that are buried by the Wapiti Formation. The volcanic 
cover contains numerous irregular to dikelike bodies of calcibreccia. These features are diagrammatically shown to the center and left in figure 10. The fault contact between the block of Madison Limestone and the underlying basal bed of the Bighorn Dolomite is well exposed, and no carbonate fault breccia or volcanic breccia occur there. This block, as well as numerous other blocks of the Madison Limestone resting on the fault surface, are considered to have toppled off the trailing edge of a larger mass and come to rest on the surface of tectonic denudation before the overlying volcanic rocks were deposited (Pierce, 1957).

Also in area 2, a yellow-weathering calcibreccia commonly containing a small amount of volcanic rock is irregularly distributed between the basal bed of the Bighorn Dolomite and the overlying Wapiti Formation; a thin zone of mixed carbonate and volcanic breccia at the base of the volcanic cover overlies the layer of calcibreccia. The contact between the Wapiti Formation and the calcibreccia dike shown in figure 11 suggests that the volcanic rocks were not fully consolidated at the time of contact with the calcibreccia. Apparently, a considerable amount of fault breccia lay loose on the fault surface in this area as a result of the cataclysmic fault movement because a layer of calci breccia 1 to $2 \mathrm{~cm}$ thick is plastered irregularly onto the sides and top of the block of Madison Limestone, as shown in figure 10. The contact between the Madison and the calcibreccia is sharp and distinct, that between the calcibreccia and mixed breccia is less distinct, and that between the mixed breccia and the Wapiti Formation is least distinct.

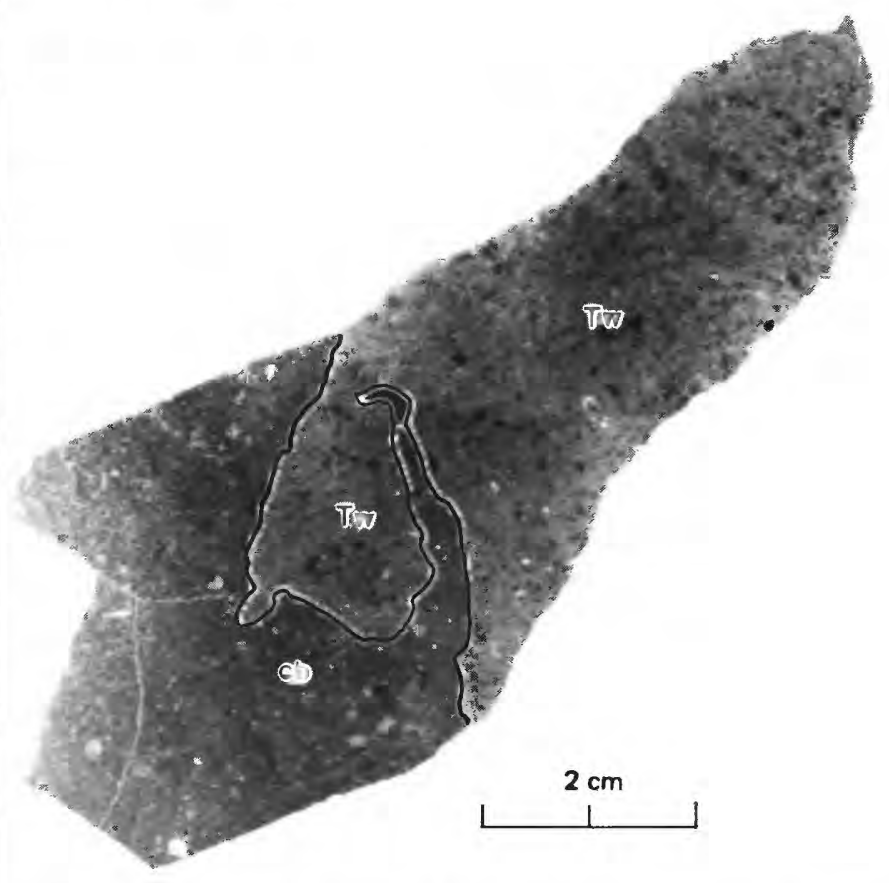

Figure 11.-Polished specimen of calcibreccia dike in area 2, on east side of Falls Creek. Curving plume of calcibreccia (cb) extending into the Wapiti Formation (Tw) suggests semifluid mixing. Photograph by Lowell Kohnitz.

Numerous irregular pods and dikelike masses as much as $1 \mathrm{~m}$ across, commonly tapering into short dikelike forms composed of light-tan- to yellowishweathering calcibreccia, occur in the basal 1 to $2 \mathrm{~m}$ of the Wapiti Formation in area 2. The central parts of

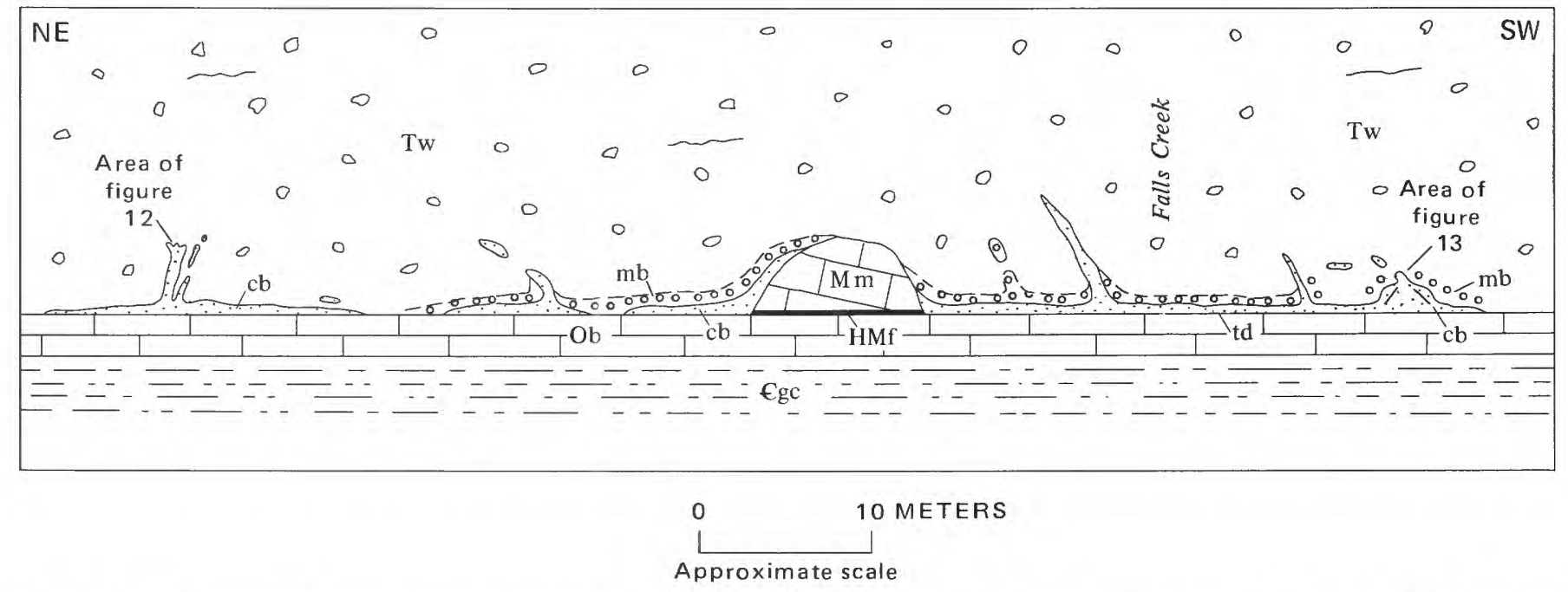

Figure 10.-Diagrammatic cross section in area 2, southeast of Silver Gate, Mont., illustrating relation of calcibreccia to Heart Mountain fault (HMf), surface of tectonic denudation (td), and the Wapiti Formation (Tw). Mm, Heart Mountain fault block of Madison Limestone; $\mathrm{cb}$, fault breccia (calcibreccia) on surface of tectonic denudation and in dikes and irregular bodies in the Wapiti Formation; mb, mixture of calcibreccia and volcanic breccia; Ob, basal bed of Bighorn Dolomite; $\mathrm{Ggc}$, Grove Creek Limestone Member of the Snowy Range Formation. Not to scale. 
these bodies usually consist almost entirely of calcibreccia and a few volcanic fragments, although some pods contain numerous small lenses and inclusions of volcanic rock as much as a few centimeters across. The outer parts of the calcibreccia bodies generally contain more volcanic rock than the inner parts, and the adjoining wallrock contains some calcibreccia. The contacts between some calcibreccia masses and the enclosing Wapiti Formation are sharp and distinct, but other contacts are gradational. Not uncommonly, a single calcibreccia mass may display both kinds of contacts. A few meters higher up in the Wapiti but usually within the lower $10 \mathrm{~m}$ of the volcanic rocks, the calcibreccia occurs in dikelike bodies a few meters long and as much as $0.3 \mathrm{~m}$ across. These bodies commonly contain some volcanic rock derived from the enclosing Wapiti Formation, and the adjoining rocks also contain some calcibreccia (fig. 12).

An exceptionally well exposed body of calcibreccia in a cliff $15 \mathrm{~m}$ west of Falls Creek in area 2 (fig. 13), in the same mass of the Wapiti Formation as dikes on the east side of the creek (fig. 10), forms a unique feature about $2 \mathrm{~m}$ high, slightly resembling an anticlinal fold-not a true fold, but apparently related more to flowage than folding. For lack of a better term, this feature is here referred to as an antiform. The base of this body is exposed to within $1 \mathrm{~m}$ of the Heart Mountain fault and presumably extends downward to the fault; $2 \mathrm{~m}$ to the west (right, fig. 13), the Wapiti

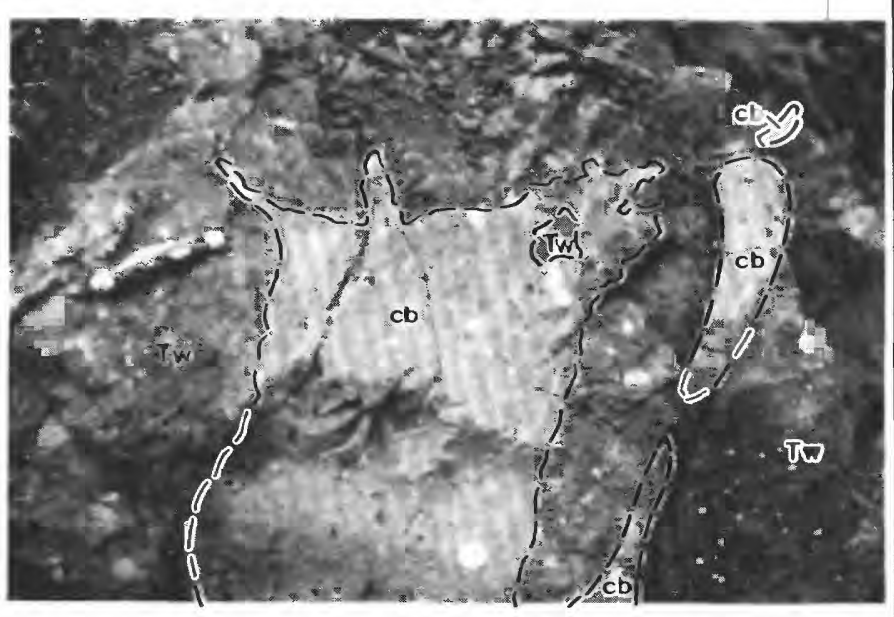

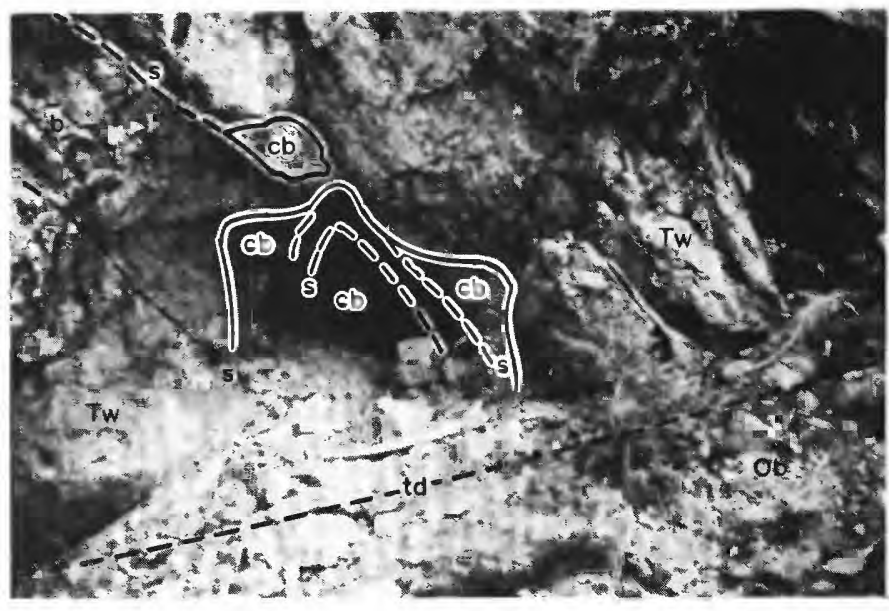

FIGURE 13.-View southwest along trend of an antiform, or calcibreccia mass resembling an anticlinal fold, at base of the Wapiti Formation (Tw) in area 2, $15 \mathrm{~m}$ west of Falls Creek. Shearing surfaces $(\mathrm{s})$ in inner part of the calcibreccia $(\mathrm{cb})$ also have an anti clinal form. Irregular masses of calcibreccia border flanks of antiform, and lozenge-shaped mass of calcibreccia lies in a shear plane along right flank of the antiform. To right, the Wapiti Formation rests on Heart Mountain fault surface of tectonic denudation (td) and on basal bed of Bighorn Dolomite (Ob). The Wapiti Formation near and adjoining calcibreccia is calcareous, a feature suggesting that some calcibreccia became mixed with it during deposition on the fault surface.

Formation can be seen to rest on the fault surface. The absence there of carbonate fault breccia is not surprising, however, inasmuch as the fault breccia was swept off the fault surface into the antiform. The calcibreccia on the flanks of the antiform is composed of angular carbonate fragments, less than 1 to a few millimeters across, bonded in a carbonate matrix containing scattered angular fragments of volcanic rock 2 to $8 \mathrm{~cm}$ across. Polished specimens of the calcibreccia do not show any distinct or layered orientation of fragments, although a few thin, wavy layers a few centimeters long of contrasting material suggest flowage. The volcanic breccia of the Wapiti Formation in which the antiform occurs is highly sheared and fractured on the flanks of and above the antiform; these features become less distinct and disappear farther out on the flanks. The Wapiti Formation above this body is inaccessible, but the lines of shear that can be observed from a distance are inclined at about $45^{\circ}$ parallel to the inner shearing surfaces (fig. 13) and apparently die out upward in an inverted " $V$ ". The fact that the steeper side of the antiform lies on the southeast suggest a movement from northwest to southeast; the fault surface, on which the Wapiti Formation was deposited (that is, the surface of tectonic denudation), sloped to the southeast in the general direction of movement along the Heart Mountain fault. 


\section{AREA 3, NORTH OF REPUBLIC MOUNTAIN}

In area 3 , on the north side of Republic Mountain, several calcibreccia dikes occur in the eastern part of a highly brecciated and fractured limestone mass that probably belongs to the Jefferson Formation (fig. 26). One dike, $8 \mathrm{~m}$ long and as much as $15 \mathrm{~cm}$ wide, extending to within about $1.5 \mathrm{~m}$ of the Heart Mountain fault, consists essentially of carbonate rock with some specks of asphalt; no volcanic rock was observed. A few meters east of this dike, an irregular but somewhat linear mass as much as $1 \mathrm{~m}$ across of calcibreccia of the same composition has sharp contact with the enclosing limestone, which is contorted, deformed, and brecciated. The fact that this deformation does not extend to any of the calcibreccia dikes or to their contacts with the limestone is convincing evidence that injection of the dikes occurred after the enclosing rock was deformed.

Overlying this brecciated limestone block are volcanic rocks of the Wapiti Formation, the lower $1 \mathrm{~m}$ or so of which contains a few scattered angular xenoliths of Precambrian rock. Along the contact and within the basal few meters, thin irregular streaks and discontinuous layers of calcibreccia occur; several short, thin calcibreccia dikes extend several meters upward from the contact into the Wapiti Formation (fig. 14). One small dike, less than $1 \mathrm{~mm}$ wide in its lower part but increasing upward in width to several centimeters,

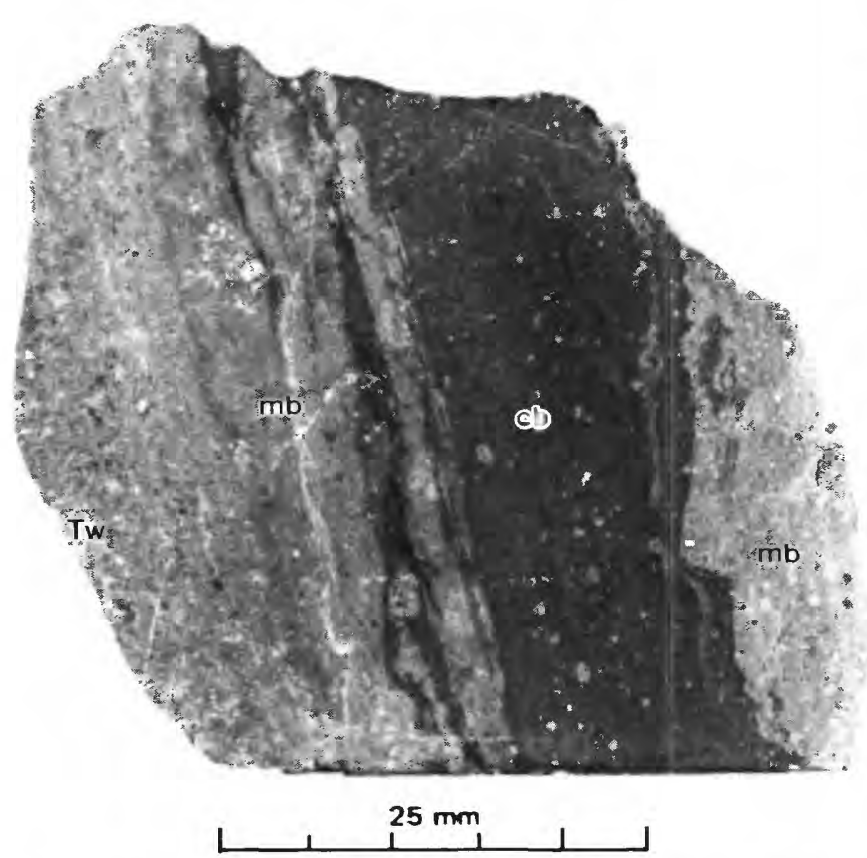

FigURE 14.-Polished specimen of calcibreccia dike in area 3, north of Republic Mountain. Mixture (mb) of calcibreccia (cb) and volcanic breccia of the Wapiti Formation (Tw) suggests that the Wapiti Formation was unconsolidated at the time the calcibreccia was intruded. Photograph by Lowell Kohnitz. seems to indicate that the lower part of the dike may have been squeezed together after the calcibreccia was injected. Such an event may explain the fact that many calcibrecci dikes cannot be traced to their points of origin within the underlying Heart Mountain fault breccia.

\section{AREA 4, SOUTH OF PILOT CREEK}

Area 4 is about $1 \mathrm{~km}$ south of Pilot Creek, near the foot of a waterfall of a north-flowing stream that heads on the west side of Jim Smith Peak. The Grove Creek Limestone and the basal bed of the Bighorn Dolomite, which has the Heart Mountain fault surface of tectonic denudation at its top, are well exposed on the east side of the valley from the waterfall to a point $150 \mathrm{~m}$ north. The 2-m-thick basal bed of the Bighorn Dolomite is overlain either by carbonate fault breccia or by volcanic rocks of the Wapiti Formation. The volcanic rocks contain several dikes and irregular bodies of calcibreccia. At a site $300 \mathrm{~m}$ to the north, an upper-plate block of Madison Limestone $30 \mathrm{~m}$ long and $10 \mathrm{~m}$ high rests on 30 to $35 \mathrm{~cm}$ of fault breccia. A layer of calcibreccia $0.7 \mathrm{~m}$ thick (figs. 15, 16), exposed $100 \mathrm{~m}$ north of the waterfall, rests on the basal bed of the Bighorn Dolomite and is overlain in turn by the Wapiti Formation. No volcanic rock was observed at these sites in the fault breccia, which consists almost entirely of carbonate rock and a few very fine fragments of chert. A murky-brown submicroscopic matrix in the uppermost part of a polished specimen of the breccia (fig. 16) gives that part a darker color.

Also in area 4,15 m north of the basal bed of the Bighorn Dolomite shown in figure 15, a mound of Heart Mountain fault breccia almost $2 \mathrm{~m}$ high rests on the basal bed of the Bighorn Dolomite and is adjoined and was overlain by the Wapiti Formation (fig. 17). A polished specimen that was collected near the top of this mound of breccia (fig. 18) is composed entirely of carbonate rock displaying a well-defined wavy to crinkled layering. A specimen from the lower part of the mound is similar, except that high-angle offsets of 1 to $2 \mathrm{~mm}$ in the layering are more numerous than in the upper part. It is suggested that the crinkled, wavy layering with high-angle offsets may reflect strong earth tremors at the time the fault breccia was unconsolidated.

The Wapiti Formation, which overlies the Heart Mountain fault in area 4 , contains several calcibreccia dikes, some near the fault and others higher up, even as much as 20 to $35 \mathrm{~m}$ above the fault. One dike lower down is distinctly layered parallel to the dike walls, and nonspherical fragments in the dike are similarly alined (fig. 19). The contact between the dike and the enclosing volcanic rock is irregularly convolute. Many 


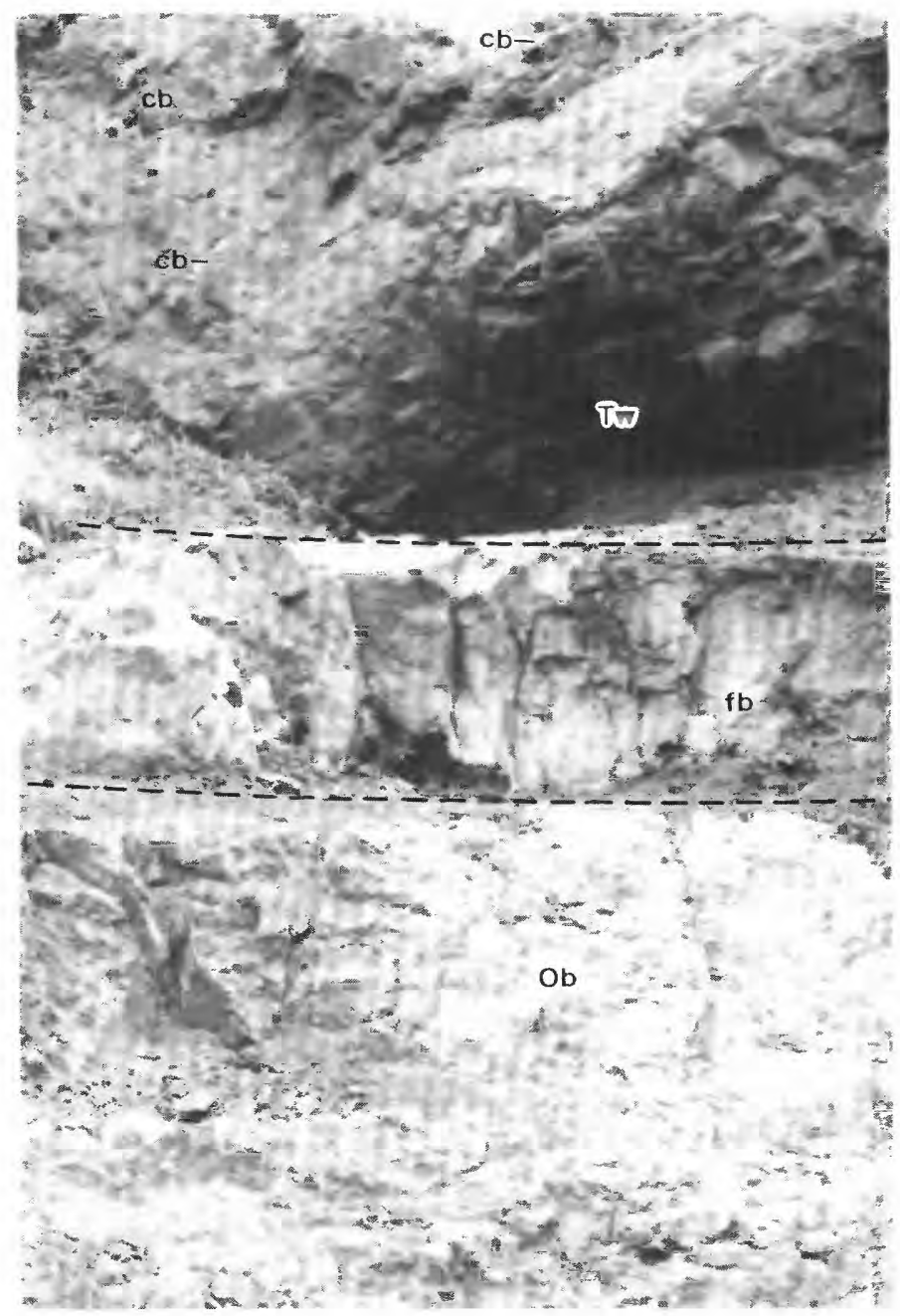

FIGURE 15.-Heart Mountain fault breccia (calcibreccia) on fault in area 4, south of Pilot Creek; Ob, basal bed of the Bighorn Dolomite; $\mathrm{fb}$, fault breccia. The Wapiti Formation (Tw) is cut by small dikes of carbonate fault breccia (cb). Head of hammer marks base of fault breccia.

of the dikes in this area are curving in plan and inclined from vertical to $45^{\circ}$ or less, others are inclined at a very low angle, and a few are nearly horizontal. One that is $1 \mathrm{~m}$ thick and inclined at $35^{\circ}$ has a fluted top and is $10 \mathrm{~m}$ above the Heart Mountain fault; it consists mostly of carbonate rock, probably dolomite, because it effervesces slowly on acid treatment and contains, in addition, some volcanic material. Another calcibreccia dike (fig. 20) is nearly horizontal and pinches and swells irregularly.

About $15 \mathrm{~m}$ further east and $35 \mathrm{~m}$ above the Heart Mountain fault is an irregular dikelike mass of calcibreccia 0.5 to $0.7 \mathrm{~m}$ thick and $7 \mathrm{~m}$ across, composed mostly of carbonate rock; its east border is steeply inclined to vertical, and the west margin is inclined

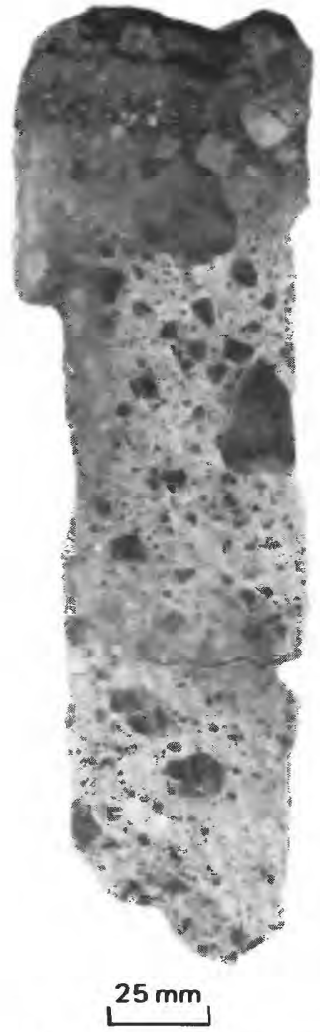

Figure 16.-Polished specimen of upper third of Heart Mountain fault breccia, showing its angular character. Top of specimen is at contact with the overlying Wapiti Formation. Photograph by Lowell Kohnitz.

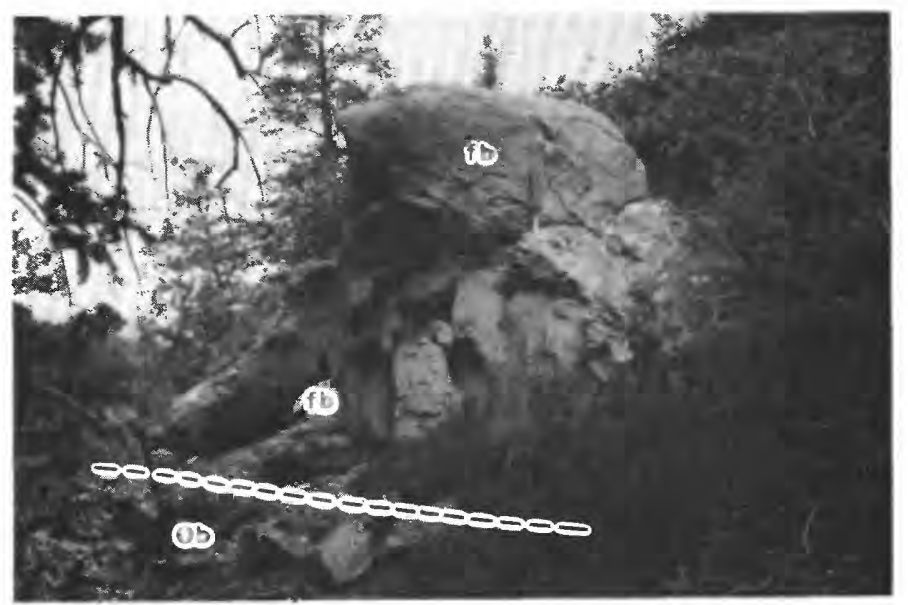

FIGURE 17.-Mound of Heart Mountain fault breccia ( $\mathrm{fb}$ ) in area 4, south of Pilot Creek. The mound, nearly $2 \mathrm{~m}$ high, is composed entirely of carbonate breccia and rests on the basal bed of the Bighorn Dolomite (Ob). 


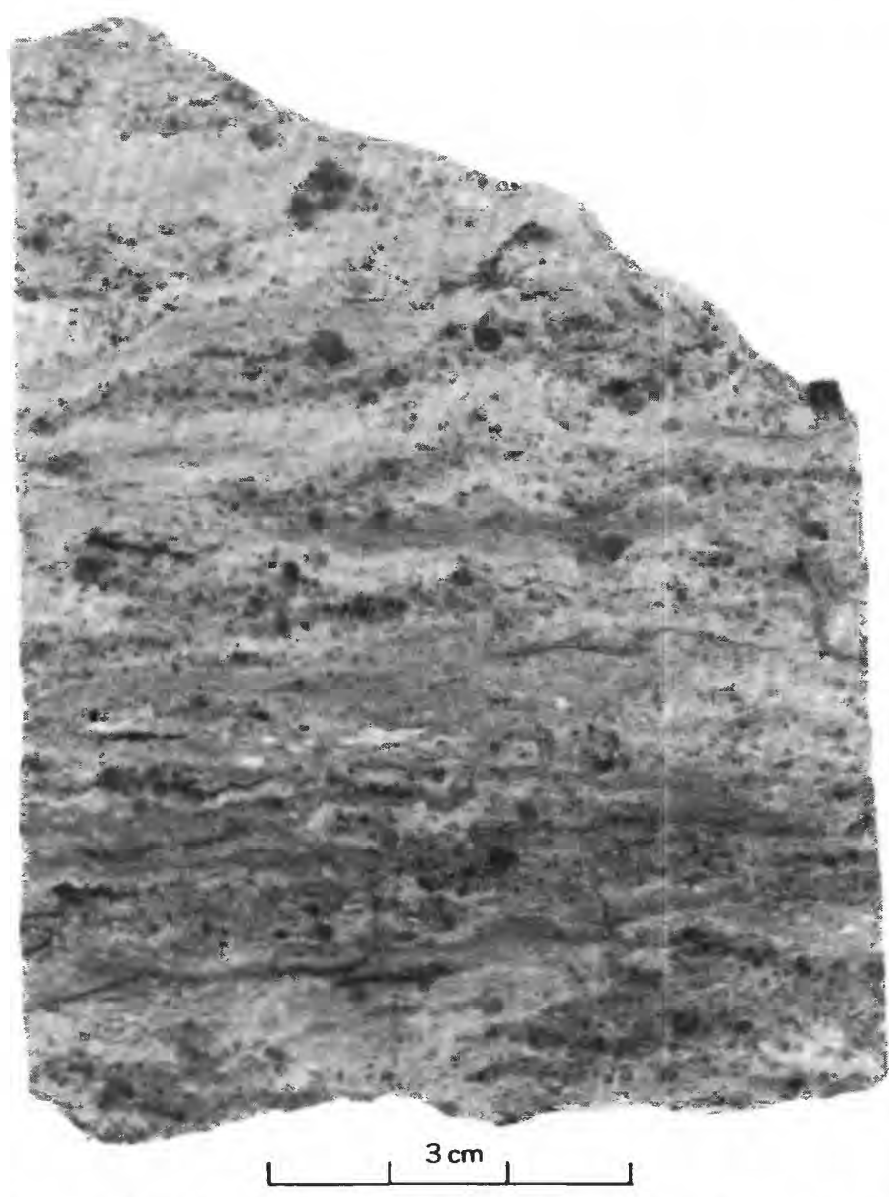

Figure 18.- Polished specimen of calcibreccia from near top of 2-m-high mound in figure 17. Note unusual crinkled, wavy layering. Photograph by Lowell Kohnitz.

about $20^{\circ}$. As revealed in a polished specimen, a $1-\mathrm{cm}-$ thick layer of calcibreccia adjoining the volcanic country rock is finer grained than the rest of the calcibreccia in the dikelike mass but is not layered and shows no distinct orientation of fragments. The bloblike mass, which crops out $15 \mathrm{~m}$ or more east of the other calcibreccia bodies, could not be traced downward; it exhibits a sharp but highly irregular contact with the volcanic wallrock, which is darker than the rock enclosing the other calcibreccia bodies.

\section{AREA 5, NORTH OF JIM SMITH PEAK}

Area 5 is about $0.5 \mathrm{~km}$ east of area 4 and extends southeast for $1.5 \mathrm{~km}$ along the Heart Mountain fault to Jim Smith Creek, which crosses the fault northeast of Jim Smith Peak. In the northwestern part of this site, two large upper-plate blocks of Madison Limestone, each about $80 \mathrm{~m}$ long and 20 to $35 \mathrm{~m}$ high, as well as three smaller upper-plate blocks, one of Madison Limestone and the other two of the Three Forks and Jeffer-

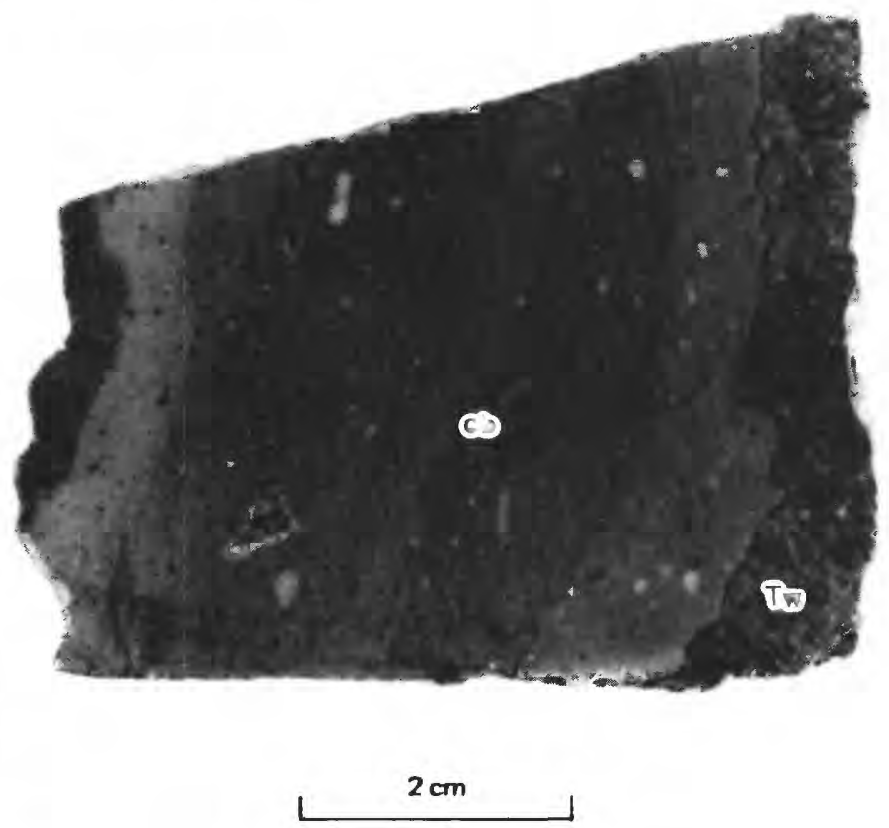

FIGURE 19.-Polished specimen of calcibreccia dike (cb) in lower part of the Wapiti Formation (Tw) in area 4, south of Pilot Creek, showing irregularly convolute contact with wallrock and layering parallel to dike wall. Photograph by Lowell Kohnitz.

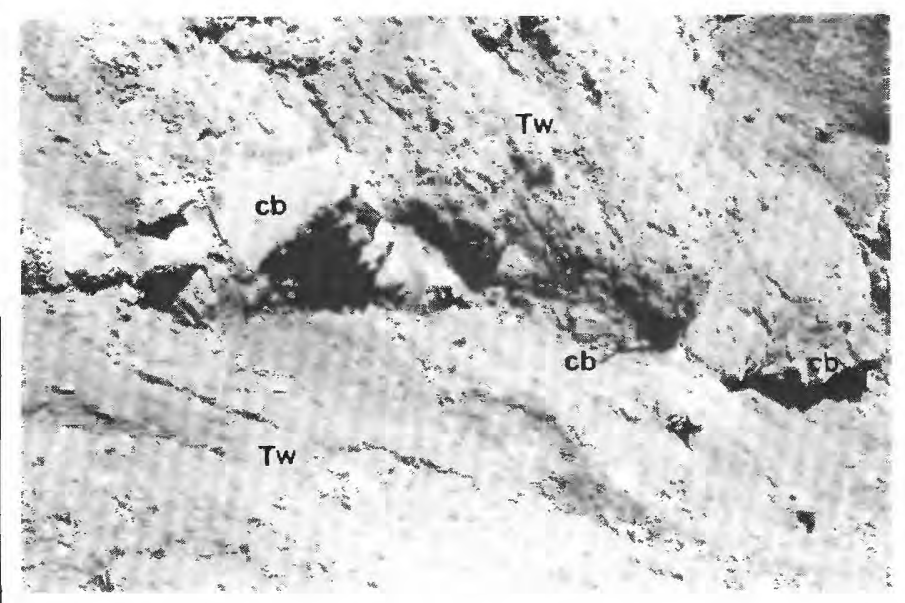

Figure 20.-Flat-lying calcibreccia dike (cb) in area 4, south of Pilot Creek. Dike pinches and swells irregularly and is about $20 \mathrm{~m}$ above base of the enclosing Wapiti Formation (Tw), which rests on the Heart Mountain fault surface of tectonic denudation.

son Formations, rest on the basal bed of the Bighorn Dolomite, which is of less than its normal thickness here. Underlying the large block of Madison Limestone farthest to the northwest is 5 to $8 \mathrm{~cm}$ of fault breccia; no volcanic rock fragments occur in the fault breccia or in the adjoining rocks. About $35 \mathrm{~m}$ southeast of this large block, a smaller block of Madison Limestone, about $5 \mathrm{~m}$ high and $8 \mathrm{~m}$ across, crops out in the middle of a steep 
ravine. Adhering to the top of the small block is an irregular layer of mixed calcibreccia and volcanic breccia 0.5 to $4 \mathrm{~cm}$ thick; resting on the breccia layer are volcanic rocks of the Wapiti Formation, the lowermost several centimeters of which contains lenses of mixed calcibreccia and volcanic breccia (fig. 21). The wavy to cuspate contact between the calcibreccia lenses and the volcanic rocks indicates that both rock types were unconsolidated at the time of intermixing.

Between these upper-plate limestone blocks just described and Jim Smith Creek, which heads just east of Jim Smith Peak, the Heart Mountain fault is well exposed along steep ravines. Along this segment of the fault the Wapiti Formation rests on the basal bed of the Bighorn Dolomite, which ranges in thickness from less than $1 \mathrm{~m}$ near Jim Smith Creek to $2 \mathrm{~m}$ in the area to the west. At the bottom of a ravine $50 \mathrm{~m}$ west of the creek, $1 \mathrm{~m}$ of the Heart Mountain fault breccia rests on this basal bed. This carbonate fault breccia, which has considerable volcanic rock mixed with it, including abundant angular and subangular volcanic fragments from 0.5 to $15 \mathrm{~cm}$ across, is overlain by Wapiti rocks showing no evidence of tectonic brecciation. At this same site, a small calcibreccia dike $15 \mathrm{~cm}$ thick extends upward from the fault breccia into the Wapiti Formation, and several other calcibreccia dikes of similar size occur nearby in the lowermost part of the volcanic rocks. In some places the base of the volcanic rocks has some carbonate rock mixed with it, and in others it does not. Where carbonate rock occurs, it is either intimately mixed with the volcanic rocks or forms irregular stringers or layers, such as the one shown in figure 22.

Prostka (1978, p. 430-431) has suggested that in the area north of Jim Smith Peak (areas 4 and 5 of this report), rocks from the top part of Heart Mountain fault blocks have spilled forward over the leading edge of the blocks, owing to their momentum as the fault blocks were coming to rest; these features he called "low-angle ramp structures or spillovers." He cited as evidence steep dips to the southeast - in the direction of sliding-on the leading edges of volcanic rocks; low-angle ramp structures were found to occur only on the leading edges of volcanic fault masses, whereas the trailing edges and sides of blocks are steep. He concluded "e**** that the ramp structures were not caused by simple collapse and slumping of steep slopes, but that the momentum of the moving volcanic masses was necessary to produce the spillovers." He believed that these volcanic rocks are fault emplaced, but to me the relation between the Heart Mountain fault breccia and the volcanic rocks resting on the Heart Mountain fault (figs. 15-17, 21, 22), as well as the occurrence of calcibreccia dikes, indicates that the volcanic rocks were deposited on the fault surface.

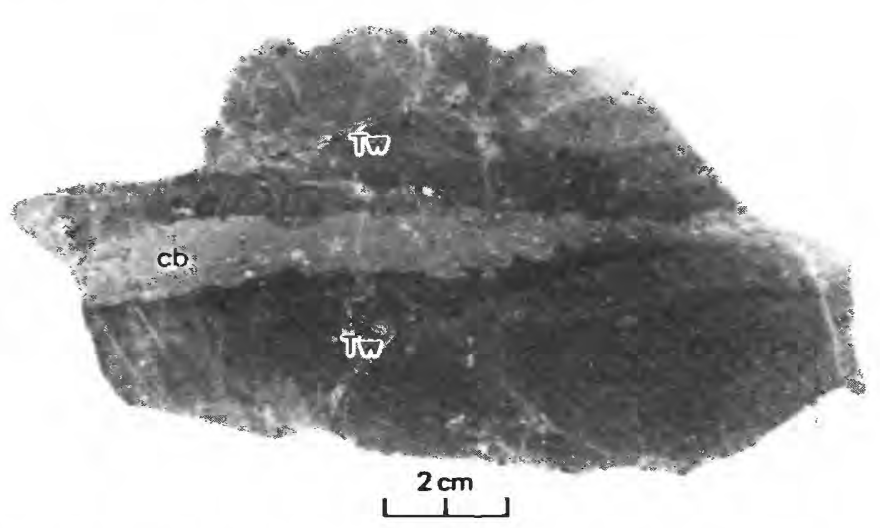

FIGURE 21.-Polished specimen of calcibreccia (cb) interlayered with basal part of the Wapiti Formation (Tw) in area 5, north of Jim Smith Peak. Inasmuch as calcibreccia was formed concurrently with the Heart Mountain fault movement, the volcanic rocks with which it is interlayered must be postfaulting. Wavy to cuspate interlayering indicates that the volcanic rock was unconsolidated at the time the calcibreccia was mixed with it. Photograph by Lowell Kohnitz.

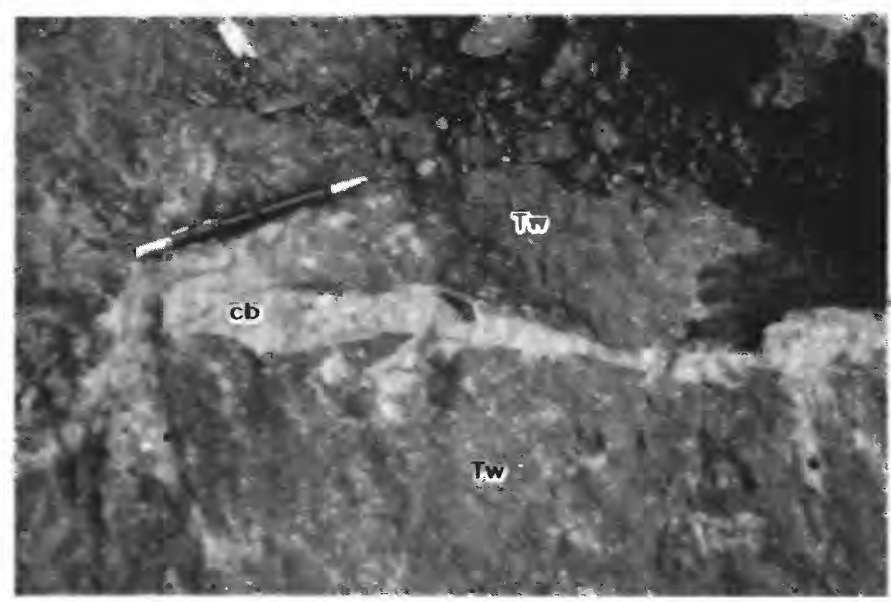

Figure 22.-Irregular layer 2 to $5 \mathrm{~cm}$ thick of carbonate breccia or calcibreccia (cb) $1.5 \mathrm{~m}$ above base of the Wapiti Formation (Tw) in area 5, west of Jim Smith Creek. Volcanic breccia also has carbonate breccia intimately mixed with it.

Observations mentioned above in discussing areas 4 and 5 negate the spillover concept and indicate that most of the volcanic rocks are depositionally emplaced in these areas. Several small fault blocks of Paleozoic carbonate rock north of Jim Smith Peak, shown on the geologic map of the Pilot Peak quadrangle (Pierce and others, 1973), rest on the Heart Mountain fault. Volcanic rocks overlie these blocks and extend downward to the fault surface, as shown in figures 3 and 10. Four exposures of fault breccia-one overlain by volcanic rock (fig. 15) and three overlain by Paleozoic rocksconsist entirely of carbonate fault breccia that contains 
no volcanic material. These occurrences of carbonate fault breccia without volcanic material are incompatible with Prostka's spillover concept and with his conclusion that all of this volcanic rock is fault emplaced as part of the Heart Mountain fault movement.

\section{AREA 6, NEAR WHITE MOUNTAIN}

In area 6 , near White Mountain, calcibreccia dikes occur in upper-plate rocks on the southwest side of the mountain and at sites 1,900 and $2,100 \mathrm{~m}$ to the eastnortheast(Nelson and others, 1972, fig. 4). At the site 1,900 $\mathrm{m}$ away, some fragments and disconnected pieces of igneous dike rock occur in a broken and faulted upper-plate block of the Bighorn Dolomite. One of the calcibreccia dikes at this locality passes through one of the igneous dike fragments, a feature indicating that the igneous rock is older than the clastic dike of Heart Mountain fault breccia and evidence compatible with the conclusion of Nelson, Pierce, Parsons, and Brophy (1972) that some of the igneous dikes at White Mountain are older than the Heart Mountain fault movement. Above and to the northeast of the block containing calcibreccia dikes in the Bighorn Dolomite, a well-exposed high-angle fault brings the Jefferson Formation into contact with the Bighorn Dolomite; however, no fault breccia occurs along this fault, nor has fault breccia similar to that in the calcibreccia dikes been found in the numerous other high-angle faults mapped at White Mountain. Furthermore, although calcibreccia dikes occur along fractures in the upper plate, the trends of many clastic carbonate dikes at White Mountain are too irregular for the enclosed carbonate material to have been fragmented by movement of one side of the dike relative to the other ( $\mathrm{Nel}-$ son and others, 1972).

At the site $200 \mathrm{~m}$ farther northeast, two clasts of dark-gray shale less than $1 \mathrm{~m}$ apart are enclosed in about the middle of a calcibreccia dike in dolomitic limestone, about $2 \mathrm{~m}$ thick and dipping $25^{\circ}$ west: one is $15 \mathrm{~cm}$ across and well rounded, the other about $13 \mathrm{~cm}$ long, $3 \mathrm{~cm}$ across, and well tapered at both ends. Although both clasts resemble and presumably were derived from the Three Forks Formation, it is not known whether they came from the fault breccia or from the wallrock. The dike itself pinches out about $7 \mathrm{~m}$ above the clasts.

The calcibreccia dikes on the southwest side of White Mountain are unusual in that they intrude a block of Paleozoic rock of the upper plate that is metamorphosed and strongly folded in contrast to other Heart Mountain fault blocks. This metamorphism ends abruptly downward at the Heart Mountain fault. Rounded fragments of carbonate rock in the fault brec- cia show that the metamorphism occurred before fault movement. Another unusual feature of these calcibreccia dikes is that they contain abundant fragments of igneous rock. These dikes can be traced down to a thick layer of fault breccia at the base of the upper plate that is similarly rich in igneous fragments derived from igneous dikes injected into the upper plate before it was emplaced by the Heart Mountain fault movement (Nelson and others, 1972). However, the absence of such fragments in the shale-containing dike $2,100 \mathrm{~m}$ east-northeast and in the closest body of fault breccia $600 \mathrm{~m}$ northeast suggests that the source of the calcibreccia in each dike was fault breccia from within a very limited area. If, as seems likely, the carbonate dikes containing igneous fragments were derived from a small body of fault breccia at the base of the upperplate block that contains them, then these dikes must have have been injected after the upper-plate block was emplaced.

\section{AREA 7, WEST OF TROUT CREEK}

Area 7 lies on the west side of Trout Creek, at the south tip of a narrow strip of upper-plate Madison Limestone that is bordered and partly overlapped on the west by volcanic rocks of the Wapiti Formation, which were deposited on the Heart Mountain fault surface (the surface of tectonic denudation). The volcanic rocks in area 7 are for the most part flow breccia but include some lighter, hornblende-bearing polybreccia similar to the Cathedral Cliffs Formation. The vertical contact between the volcanic rocks and the upper-plate block of Madison Limestone is well exposed and accessible in the lower and upper parts of a steep face $100 \mathrm{~m}$ high but inaccessible in the intermediate part. At the lower exposure, lenses and stringers of calcibreccia occur in a dike about $3 \mathrm{~m}$ wide, somewhat variable and irregular in width, composed of volcanic rocks of the Wapiti Formation (fig. 23), similar to the dikes of volcanic rock containing calcibreccia described in the section "Area 1, South of Silver Gate, Montana." (See figs. 4,6 , and 8.) The contact between this dike of volcanic rock and the Madison Limestone is sharp but irregular to wavy, and the adjoining limestone is not sheared or brecciated. On the other hand, the contact between volcanic breccia of the dike and the Wapiti Formation is indistinct because their compositions are much the same, the only differences being the vague, more or less horizontal flow lines in the Wapiti Formation, the presence of carbonate breccia in the dike, and the steep to vertical shears in the volcanic breccia of the dike (fig. 24).

The calcibreccia stringers in the dike are vertically alined and occur in a zone about $1 \mathrm{~m}$ wide adjacent to the limestone. Vertical lineations and striations in the 


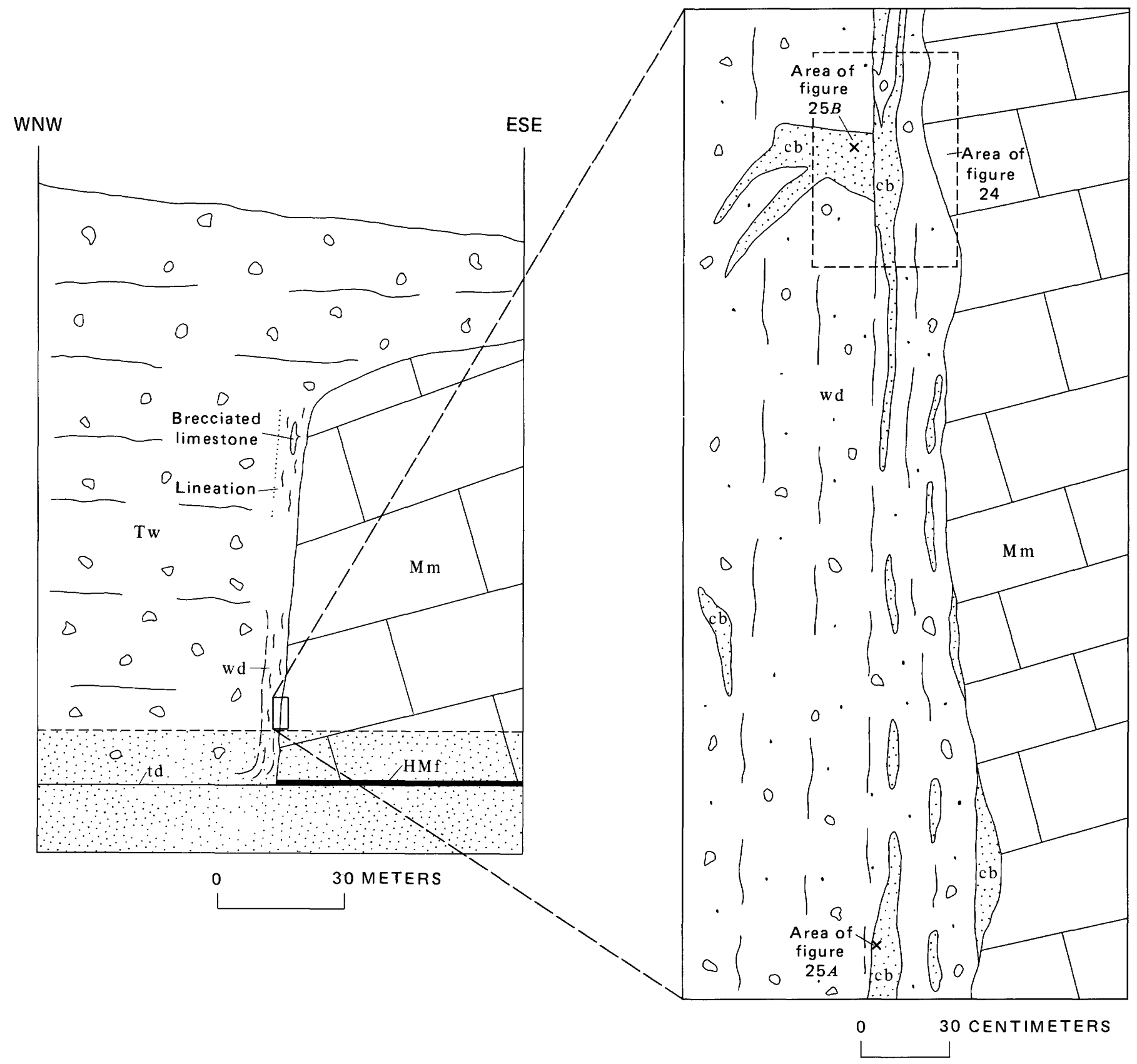

FIGURE 23.-Cross section in area 7, on west side of Trout Creek, showing relations of a dike of the Wapiti Formation (wd) enclosing irregular stringers of carbonate fault breccia (cb) to country rocks of the Wapiti Formation (Tw) and an upper-plate block of Madison Limestone $(\mathrm{Mm})$. Scattered dots in dike of Wapiti Formation indicate some intermixed carbonate rock. Stippled area at bottom of left diagram indicates talus cover. Heart Mountain fault (HMf) and surface of tectonic denudation (td), which are obsured by talus, lie about $20 \mathrm{~m}$ below lowermost exposure.

dike of volcanic rock are also most pronounced in this zone. The part of this zone that could be observed and sampled lies in the lowermost $4 \mathrm{~m}$ of outcrop, above which it becomes inaccessible and apparently contains no calcibreccia because none could be seen from a distance. Most calcibreccia stringers are irregularly layered parallel to the dike walls (fig. 25A) and are composed almost entirely of carbonate breccia, even near the contact with the enclosing volcanic breccia. One irregular calcibreccia pod (upper left of enlarged diagram, fig. 23), however, exhibits irregular wavy bands, and the irregular, nonparallel banding is horizontal to inclined rather than vertical (fig. $25 B$ ). The presence of carbonate rock in the volcanic matrix ad- 


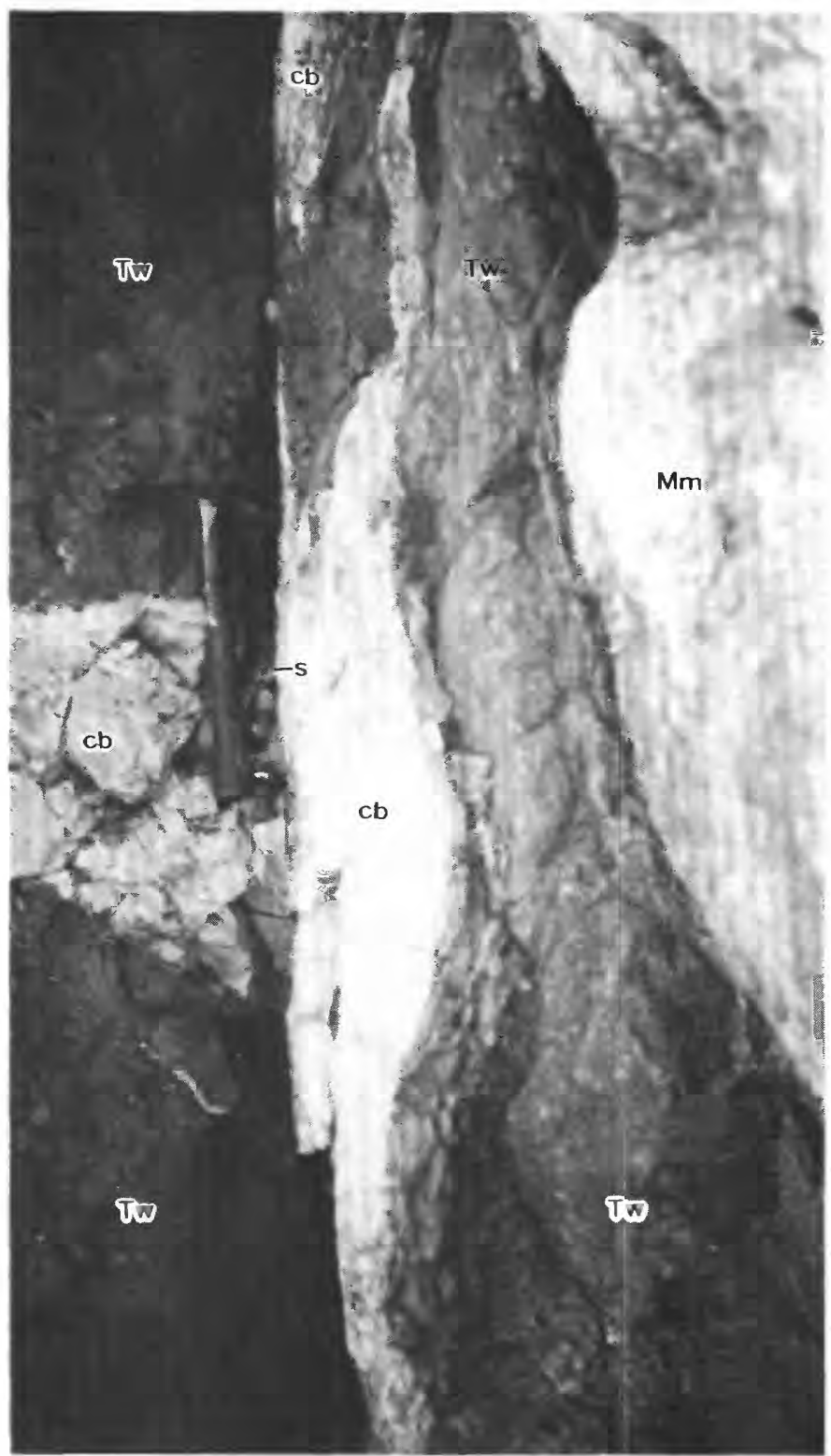

Frgure 24.-Dike of volcanic breccia of the Wapiti Formation containing calcibreccia (cb) in contact with edge of a Heart Mountain fault block of Madison Limestone in area 7, west of Trout Creek. Note sharp, irregular to wavy contact between the Wapiti Formation (Tw) and the Madison Limestone ( $\mathrm{Mm}$ ), and vertical shear (s) between irregular pod of calcibreccia to left (on which hammer rests) and calcibreccia stringer on right. For relation to general area, see figure 23. Photograph by Allan Krill.

joining these stringers indicates that both the volcanic matrix and the calcibreccia were unconsolidated at the time of injection.

The upper, accessible part of the contact between the Wapiti Formation and the Madison Limestone is about $100 \mathrm{~m}$ above the lower part. Here, as in the lower part, a distinct lineation occurs in the volcanic rocks parallel to the vertical contact between them and the limestone
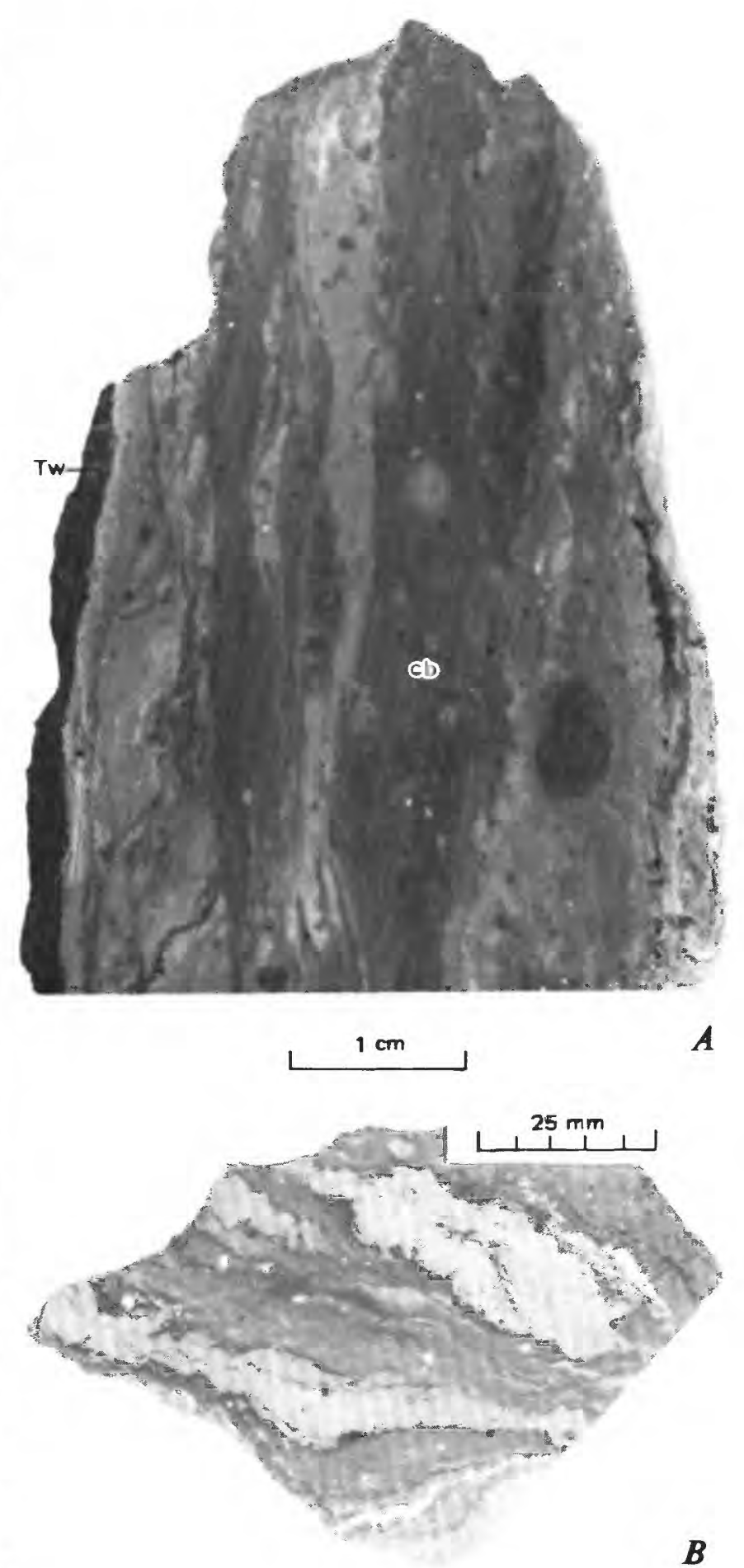

Figure 25.--Polished specimens of calcibreccia from a dike of volcanic rock in area 7, on west side of Trout Creek (see fig. 23 for locations of specimens within dike). $A$, Stringer of irregularly banded calcibreccia (cb) composed almost entirely of carbonate breccia, even along contact with volcanic rocks of the Wapiti Formation (Tw). Banding is alined with stringer wall. $B$, Irregular pod of calcibreccia. Very irregular, wavy layering is not alined vertically with wall of dike. Photographs by Lowell Kohnitz. 
(fig. 23) but does not seem to be a dikelike feature. The lineation forms a zone about $7 \mathrm{~m}$ wide that dies out irregularly westward in the volcanic rocks and upward near the top of the limestone (fig. 23). The lineation seems to be a flowage feature apparently formed as the volcanic breccia flowed along the face of the limestone block and, as it did so, cut horizontal grooves in the limestone. Near the middle of the zone is a lens of brecciated limestone, probably of Madison Limestone, about $0.7 \mathrm{~m}$ wide and $7 \mathrm{~m}$ high, with a small prong of predominantly volcanic rock extending out horizontally (fig. 23), which is exposed in a nearly vertical face so that its horizontal dimension is not measurable. Much of the limestone breccia is composed of limestone fragments 0.2 to $0.5 \mathrm{~cm}$ long, some cobble size, 8 to 15 $\mathrm{cm}$ across, quite unlike the Heart Mountain fault breccia. No stringers of calcibreccia similar to those $100 \mathrm{~m}$ below occur in the volcanic rocks, nor are these rocks calcareous; the zone of lineation disappears about $25 \mathrm{~m}$ below the lens of brecciated limestone.
Several additional small masses of calcibreccia as much as $0.7 \mathrm{~m}$ across occur in a large area of loose volcanic landslide debris near Trout Creek, $2 \mathrm{~km}$ northeast of area 7; their source is unknown.

\section{OTHER SITES OF CLASTIC DIKES}

In addition to the seven sites of clastic dikes of the Heart Mountain fault breccia that have been described above (areas 1-7, fig. 1), eight additional sites (locs. $A-H$, fig. 1) are known, information on which is summarized in the accompanying table (table 1).

\section{BRECCIA AND BRECCIATION PRODUCED BY THE HEART MOUNTAIN FAULT}

The Heart Mountain fault movement caused extensive brecciation of rocks in the lower part of the upper plate, most intense at the base and extending upward into shattered carbonate rock for as much as several

TABLE 1.-Location of and brief data on other calcibreccia dikes

\begin{tabular}{|c|c|c|c|c|}
\hline Locality & Location & Country rock & Dike size & Remarks \\
\hline $\bar{A}$ & $\begin{array}{l}\text { SE. of Miller Mountain, SW1/4NW1/4 sec. } \\
23 \text {, T. } 9 \text { S., R. } 14 \text { E., in Cooke } \\
\text { City quadrangle. }\end{array}$ & Wapiti Formation -- & $\begin{array}{l}0.15 \mathrm{~m} \text { wide, } \\
5 \mathrm{~m} \text { high. }\end{array}$ & $\begin{array}{l}\text { Calcibreccia dike terminates downward in Heart } \\
\text { Mountain fault breccia, } 0.3-1 \mathrm{~m} \text { thick, altered } \\
\text { to yellow brown color; fault breccia has sharp, } \\
\text { nontransitional contact with underlying } 65 \mathrm{~m} \\
\text { of Bighorn Dolomite, but upper contact with the } \\
\text { Wapiti Formation is irregular, with a gradation- } \\
\text { al zone of mixed carbonate and volcanic breccia } \\
\text { at top. }\end{array}$ \\
\hline$B$ & $\begin{array}{l}2 \mathrm{~km} \text { due E. of Pilot Peak on north } \\
\text { side of Fox Creek tributary, near } \\
\text { foot of } 65-\mathrm{m} \text { waterfall. }\end{array}$ & Volcanic rocks & $\begin{array}{l}0.6-1 \mathrm{~m} \text { thick, } \\
20 \mathrm{~m} \text { high. }\end{array}$ & $\begin{array}{l}\text { Dike begins at the Heart Mountain fault and curves } \\
\text { irregularly upward; near the top a 3-m-long fork } \\
\text { branches off the main dike and bluntly terminates } \\
1 \mathrm{~m} \text { beyond the fork. About } 200 \mathrm{~m} \text { to NE. at the } \\
\text { foot of a } 50-\mathrm{m} \text { waterfall on Fox Creek, a calci- } \\
\text { breccia dike } 5-10 \mathrm{~cm} \text { thick occurs near the base } \\
\text { of volcanic rocks. }\end{array}$ \\
\hline$C$ & $\begin{array}{l}\text { On north side of One Mile Creek, up- } \\
\text { stream from point where large } \\
\text { fault block crosses creek and NE. } \\
\text { of small block of Madison Lime- } \\
\text { stone surrounded by Wapiti } \\
\text { Formation. }\end{array}$ & Wapiti Formation & $\begin{array}{l}0.15 \mathrm{~m} \text { wide, } \\
50 \mathrm{~m} \text { long. }\end{array}$ & $\begin{array}{l}\text { Dike trends } N .30^{\circ} \text { W., dips } 55^{\circ} \text { NE. At short dis- } \\
\text { tance to } W \text {. are several small calcibreccia dikes, } \\
\text { each about } 15 \mathrm{~cm} \text { wide and } 1-2 \mathrm{~m} \text { long. }\end{array}$ \\
\hline$D$ & $\begin{array}{l}\text { On north side of One Mile Creek, } \\
0.8 \mathrm{~km} \text { ENE. of locality C. }\end{array}$ & do & $\begin{array}{l}0.3 \mathrm{~m} \text { wide, } \\
10 \mathrm{~m} \text { long. }\end{array}$ & Dike trends N. $10^{\circ}$ E., dips $45^{\circ} \mathrm{NW}$. \\
\hline$E$ & $\begin{array}{l}\text { In bottom of valley, } 0.5 \mathrm{~km} \mathrm{~N} \text {. of } \\
\text { One Mile Creek and } 0.2 \mathrm{~km} \text { ENE. of } \\
\text { locality D. }\end{array}$ & $\begin{array}{l}\text { Some in broken and } \\
\text { deformed lime- } \\
\text { stone, others in } \\
\text { the Wapiti Forma- } \\
\text { tion. }\end{array}$ & $\begin{array}{l}\text { In limestone: } \\
0.5-5 \mathrm{~cm} \text { wide } \\
\text { or as irregular- } \\
\text { shaped bodies. } \\
\text { In volcanic } \\
\text { rock: irreg- } \\
\text { ular masses } \\
\text { and stringers } \\
\text { as wide as } 0.3 \\
\text { m. }\end{array}$ & $\begin{array}{l}\text { The calcibreccia in the limestone is entirely } \\
\text { carbonate rock, but that in volcanic rock contains } \\
\text { some volcanic fragments. Lenses and stringers of } \\
\text { calcibreccia occur along the very irregular but } \\
\text { sharp contact between the limestone and volcanic } \\
\text { rock. The volcanic rock contains a little horn- } \\
\text { blende and is calcareous in vicinity of the cal- } \\
\text { cibreccia. The volcanic rock here appears to have } \\
\text { been unconsolidated at the time it came in con- } \\
\text { tact with the calcibreccia. }\end{array}$ \\
\hline$F$ & $\begin{array}{l}\text { On divide between North Fork Cran- } \\
\text { dall Creek and Blacktail Creek. }\end{array}$ & Wapiti Formation & $\begin{array}{l}1 \mathrm{~m} \text { wide and } 15 \mathrm{~m} \\
\text { long; pieces } \\
\text { scattered } 150 \mathrm{~m} \\
\text { along strike. }\end{array}$ & $\begin{array}{l}\text { Dike striking S. } 55^{\circ} \mathrm{W} \text {. is at unusual height of } \\
\text { about } 170 \mathrm{~m} \text { above the Heart Mountain fault. Fault } \\
\text { blocks of upper plate are exposed } 300 \mathrm{~m} \text { to } \mathrm{S} \text {. and } \\
600 \mathrm{~m} \text { to } \mathrm{E} \text {. }\end{array}$ \\
\hline$G$ & $\begin{array}{l}\text { In three areas: one near divide be- } \\
\text { tween Dead Indian Creek and west } \\
\text { fork of Paint Creek, others } 400 \mathrm{~m} \\
\text { and in ravine } 600 \mathrm{~m} \text { to SW. }\end{array}$ & do & $\begin{array}{l}\text { Dike on divide: } \\
0.15-0.3 \mathrm{~m} \text { wide, } \\
10 \mathrm{~m} \text { long, with } \\
\text { scattered frag- } \\
\text { ments for } 100 \mathrm{~m} \\
\text { SW. Dike } 400 \mathrm{~m} \\
\text { SW. represented } \\
\text { by numerous } \\
\text { fragments } 30 \mathrm{~cm} \\
\text { or more wide. }\end{array}$ & $\begin{array}{l}\text { Dikes are directly above the change in slope of the } \\
\text { Heart Mountain fault from a transgressive to a } \\
\text { former land-surface phase (fig. 1). Abrupt } \\
\text { change in slope here may have favored accumu- } \\
\text { lation of fault breccia that became the source } \\
\text { of dike rock. }\end{array}$ \\
\hline$H$ & $\begin{array}{l}\text { On ridge between two forks of Paint } \\
\text { Creek, } 0.5 \mathrm{~km} \text { SE. of an abandoned } \\
\text { CCC camp. }\end{array}$ & $\begin{array}{l}\text { Cathedral Cliffs } \\
\text { Formation }\end{array}$ & $\begin{array}{l}0.3-0.5 \mathrm{~m} \text { wide, } \\
15 \mathrm{~m} \text { or more } \\
\text { long. }\end{array}$ & $\begin{array}{l}\text { Height of dike above the Heart Mountain fault is } \\
\text { probably less than } 25 \mathrm{~m} \text {. Enclosing volcanic } \\
\text { rock dips } 25^{\circ} \mathrm{SSW} \text {. is fractured and striated, } \\
\text { and displays some slickensides. }\end{array}$ \\
\hline
\end{tabular}


tens of meters-a feature that has also been noted in the upper plate of the Muddy Mountain thrust (Longwell, 1922; Brock and Engelder, 1977). The abundant fault breccia remaining on the surface of tectonic denudation was part of the brecciation phenomenon associated with movement of the upper plate. The lower plate, on the other hand, has been thoroughly examined and nowhere shows any significant deformation that could be due to Heart Mountain faulting. This strange paradox is most probably related to the emplacement mechanism for the Heart Mountain fault.

A particularly informative example of brecciation of rocks in the upper plate is the limestone mass described in the section "Area 3, North of Republic Mountain," where calcibreccia dikes in its lower part and at the top have been described. This intensely brecciated block of limestone, which is composed mostly of Jefferson and a little Three Forks Formation at the top, lies on the Heart Mountain fault surface with the basal bed of the Bighorn Dolomite, which is dark gray here and has a petroliferous odor immediately below. The block of limestone was not only moved horizontally as a brecciated mass for some distance along the fault but also was displaced downward $100 \mathrm{~m}$ because the Bighorn Dolomite that normally underlies it is absent. How this movement was accomplished is unknown, but the consequent deformation of this upper-plate block is well preserved and will be described further as an aid in understanding the faulting process.

The brecciated limestone block is about $25 \mathrm{~m}$ high and zoned roughly into three parts of about equal thickness and varying degrees of deformation (fig. 26). The lower zone consists at base of $2 \mathrm{~m}$ of carbonate fault breccia, finely comminuted and grading into about $6 \mathrm{~m}$ of overlying intensely brecciated limestone of the Jefferson Formation. Throughout this zone, some parts of the Jefferson are slightly less brecciated than others (fig. 27), and a crude horizontal lenticularity, resembling bedding, has been preserved. A few calcibreccia dikes occur in the lower zone, some of which have already been described in area 3 . Near the top of this zone, vugs in less severely brecciated parts of the limestone block contain an asphalt residue, and some nearby breccia contains numerous blebs or specks of asphalt that give the rock a banded appearance. One indistinct calcibreccia dike in the lower zone also contains black asphalt specks.

The middle zone, which consists of about $10 \mathrm{~m}$ of several somewhat massive beds of bluish-gray limestone, is quite thoroughly brecciated but exhibits the outward form and appearance of the original sedimentary beds; on fresh fracture it has a petroliferous odor.
At the base of the upper zone, mostly unbrecciated, is a bed of limestone 2.5 thick containing many fine fractures, in places closely spaced and forming a crisscross pattern that gives a breccialike appearance, although deformation has not proceeded far enough to rotate the enclosed fragments. Above the basal bed in this zone are sheared and fractured rocks, apparently a mixture of rocks of the Jefferson and Three Forks Formations; the more massive limestone beds contain innumerable hairline fractures, and the thin-bedded limestone has been deformed by shearing and faulting.

\section{MECHANISM OF DIKE INJECTION}

An important clue to the origin of the clastic dikes of Heart Mountain fault breccia is provided by evidence that the volcanic country rock of the Wapiti Formation was unconsolidated at the time many of the dikes were intruded. Krill (1976) suggested a steam-injection model as a working hypothesis for the mechanism of dike injection, according to which the volcanic rocks were the source of heat. In this model, water in the calcibreccia was not vaporized immediately upon burial but only after burial beneath several volcanic flows (immediate vaporization is negated by the presence of dikes $20 \mathrm{~m}$ high passing through at least two distinct flows). Although this idea is interesting and imaginative, it does not seem to apply equally well at all sites, particularly those with dikes in both upper-plate and volcanic rocks.

Voight (1973a) concluded that the clastic dikes injected into upper-plate rocks are somewhat older than those in volcanic rocks but did not state the basis for his conclusion. No evidence has been found, so far as I am aware, that clastic dikes of Heart Mountain fault breccia intruded upper-plate rocks at a different time from rocks of the Wapiti Formation. The calcibreccia dikes in the Wapiti Formation were evidently injected very soon after movement on the Heart Mountain fault had ceased, and so also the dikes in the upper plate, as shown by (1) the calcibreccia dike in a small block of the Three Forks Formation in area 1 that contains volcanic fragments from the adjoining Wapiti Formation, evidence showing that it was emplaced after both deposition of the Wapiti and Heart Mountain faulting; and (2) the undeformed dikes in the highly brecciated limestone mass of the upper plate in area 3, north of Republic Mountain, which unequivocally shows that dike injection occurred after deformation of the enclosing rock and thus after faulting.

An alternative explanation for the calcibreccia dikes, proposed by Voight (1973b), is that dikes in the upper plate were injected as part of the Heart Mountain fault emplacement mechanism. Their presence was said to 


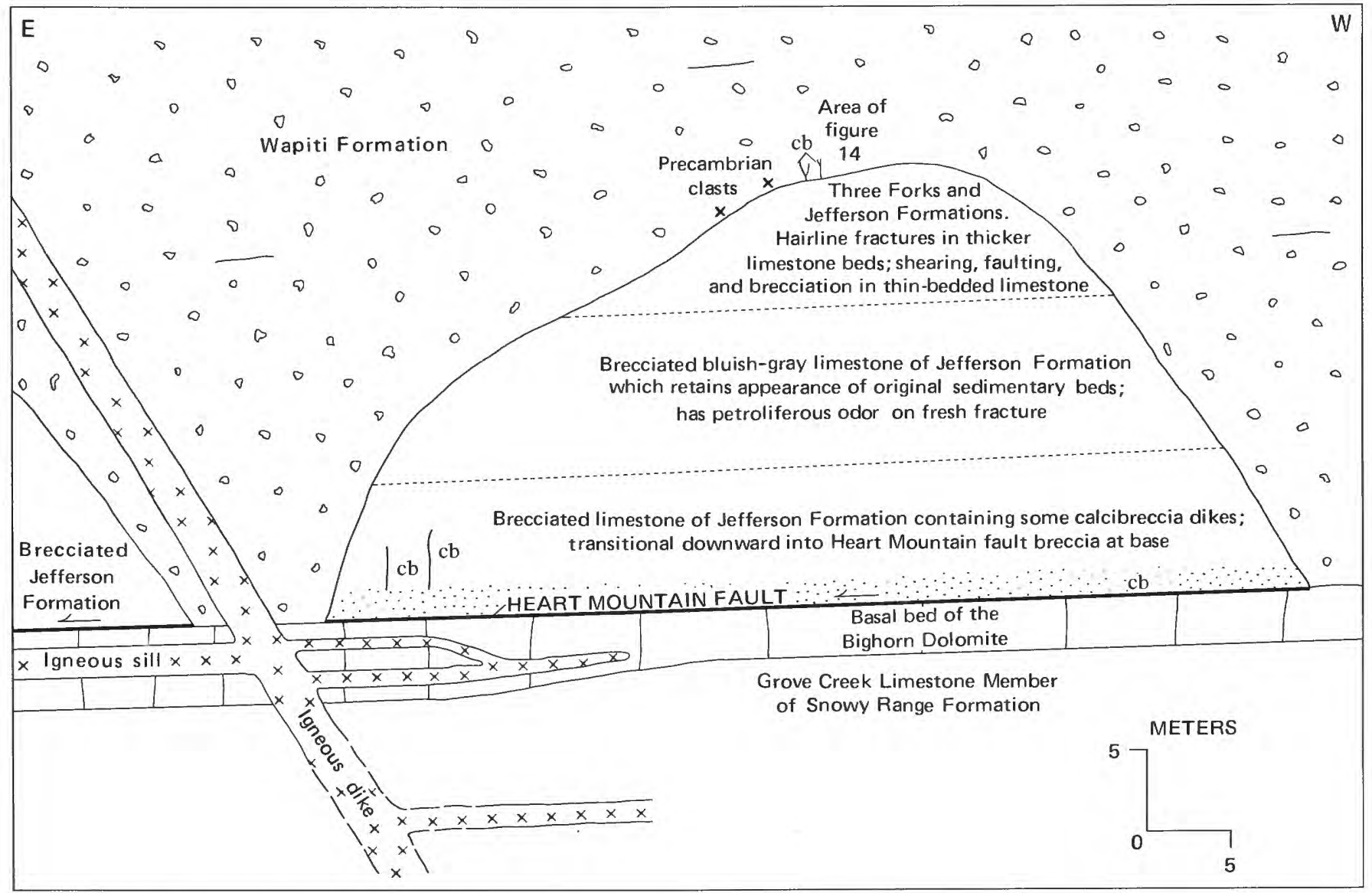

FigurE 26.-Diagrammatic cross section showing various degrees of deformation in brecciated limestone above Heart Mountain fault in area 3, north of Republic Mountain. cb, calcibreccia. Arrows show direction of movement on fault.

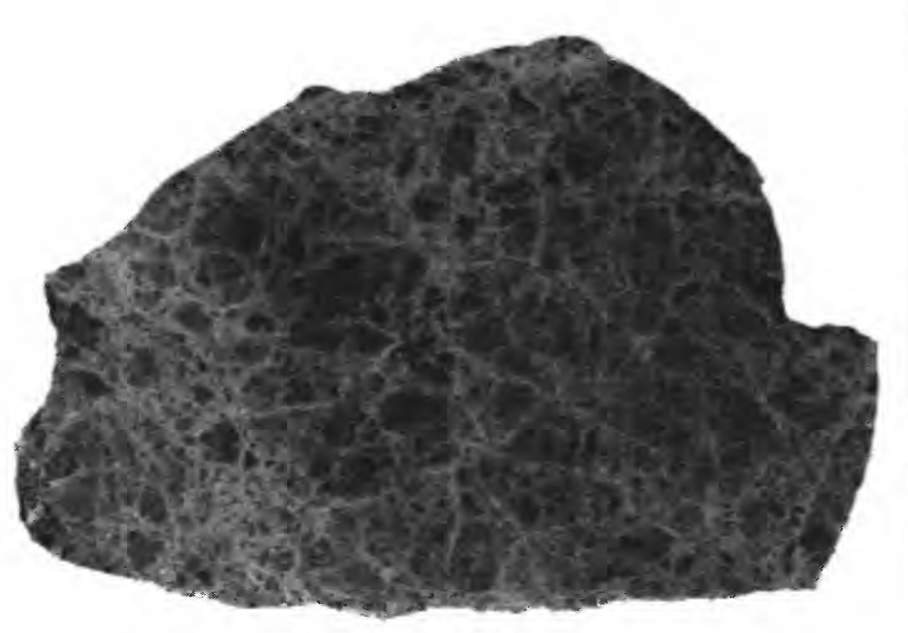

$50 \mathrm{~mm}$

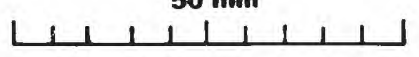

FIGURE 27.--Polished specimen of brecciated limestone from $10 \mathrm{~m}$ above Heart Mountain fault in area 3, north of Republic Mountain. Degree of brecciation is not uniform, and many fragments are not rotated. Photograph by Lowell Kohnitz.
'**** demand a fluid 'flotation' mechanism in the mechanics of the Heart Mountain rockslide [his term], and by analogy, of South Fork and Reef Creek rockslides." Several factors, however, indicate that this explanation is not correct. (1) The upper plate was under lateral tension rather than confining pressure, as shown by its having been broken up and pulled apart into numerous detached blocks during movement. In the absence of confining pressure, small upper-plate masses containing calcibreccia dikes such as those described here would simply have come apart and failed to retain the intrusions. (2) The dikes in the upper plate are not genetically related to the emplacement process because evidence indicates that they were injected some time after movement had ceased. (3) The dikes in volcanic rocks are younger than the Heart Mountain fault movement (Pierce, 1968; Voight, 1974, fig. 9). If the dikes in upper-plate rocks are not the same age but older and part of the faulting process, then different mechanisms are required for the fault breccia dikes in one type of country rock and those in another type, although the dikes are similar in all other respects. 
Voight (1974) also cited the clastic dike of fault-zone material along the Muddy Mountain thrust in Nevada as evidence for the former existence of high fluid pressure along that fault. In a recent report, however, Brock and Engelder (1977) proposed that these clastic dikes are probably not related to high fluid pressure during faulting and from several lines of evidence concluded that the advance of the Muddy Mountain thrust could not have been aided by high pore pressure.

If the premise be accepted that the calcibreccia dikes intruded both the upper-plate and volcanic rocks of the Wapiti Formation in the Heart Mountain fault area at essentially the same time, then a common mechanism for their injection seems far more likely than separate mechanisms. The model proposed here, which would satisfy all known constraints imposed by the observed data, assumes that lithostatic pressure was imposed by a rapidly accumulating overburden of volcanic rock. The sequence of events associated with dike injection may be reconstructed as follows. Once the surface of tectonic denudation had been created by catastrophic movement on the Heart Mountain fault, watersaturated carbonate fault breccia, from 0 to $4 \mathrm{~m}$ or more thick, was irregularly distributed over the fault surface. As volcanic rock was poured out onto this land surface, some of the calcibreccia was mixed with the volcanic rocks, some was caught up as irregular pods and lenses in the lower part of the Wapiti Formation, and some remained as irregular tabular bodies at the base of the volcanic rocks. These irregular bodies were unconsolidated, and so an unstable condition was formed, with the more mobile fault breccia below and the less mobile volcanic rocks above. As deposition of volcanic rocks continued, the smallest upper-plate blocks were immediately buried, and the somewhat larger ones were covered soon after. Lithostatic pressure on the unconsolidated fault breccia at the base of the upper plate increased with the thickening volcanic cover until the cohesive strength of the overlying rock was exceeded, and the calcibreccia was injected upward as dikes along fractures or lines of weakness or lesser consolidation, regardless of whether the overlying rocks were upper-plate rocks or volcanic rocks. The degree of lithostatic pressure needed to initiate intrusion of a dike into the Wapiti Formation would have depended on the degree of consolidation and the character of the volcanic rock, as well as on the fluidity of the calcibreccia; in some cases perhaps only a few tens or hundreds of meters of overburden may have been sufficient.

\section{GEOLOGIC SIGNIFICANCE OF THE CLASTIC DIKES}

The calcibreccia dikes and related features affirm some earlier conclusions regarding the Heart
Mountain fault and furnish additional data on the events associated with the fault movement.

It has already been established that the Wapiti Formation was deposited on the surface of tectonic denudation soon after the fault movement ceased because the bedding-plane phase (fig. 1) of the fault has not been altered by erosion. This conclusion can now be extended to include the transgressive and former land-surface phases of the fault because calcibreccia dikes occur in these areas as well. The significance of the dikes is that the fault breccia from which they were derived was almost immediately buried by volcanic rocks, otherwise it would have been eroded away. Rapid deposition of at least the basal part of the Wapiti Formation is now considered to have extended over the entire $75-\mathrm{km}$-long area where calcibreccia dikes are known to occur.

Voight (1973a, p. 118-119) stated that ${ }^{1 * * * *}$ the presence of fault breccia-derived dikes injected within glide blocks seem to demand a fluid flotation mechanism for the Heart Mountain structure (Voight, 1973b)." His conclusion is based on the premise that the fault breccia-derived dikes (calcibreccia dikes of this paper) were injected as part of the Heart Mountain fault movement, but he presents no evidence for this assumption. Moreover, his mechanism of dike injection is invalid because the data presented here show that the clastic dikes were not injected as part of the fault movement but only after this movement had ceased and after basal rocks of the Wapiti Formation had been deposited. Likewise, the fault breccia-derived dikes are not indicative of the other fluid-pressure mechanisms that have been suggested: the high-fluid-pressure mechanism of Hubbert and Rubey (1959) or the volcanic-gas mechanism of Hughes (1970) and Prostka (1978, p. 435).

The calibreccia dikes are useful in conjunction with the surface of tectonic denudation for a stratigraphic correlation of the various volcanic rock formations. Because this surface was exposed for only a very brief interval, the rocks deposited on it must be of the same age. The problem that arises in using this surface for stratigraphic correlation of the volcanic rocks is to determine whether these rocks were deposited on the surface or were fault-emplaced during the Heart Mountain fault movement, that is, whether the volcanic rocks have a depositional or a fault contact with the surface of tectonic denudation. If these volcanic rocks were fault emplaced, they should follow the well-known pattern of other upper-plate rocks and form fault breccia composed of volcanic rock fragments. In this case, the basal part of the rock unit in question should also show tectonic brecciation, although opinions may differ as to whether a given volcanic breccia is of tectonic or other origin. However, the presence of 
calcibreccia bodies can help to determine whether the rock is either depositional or fault emplaced because, although clastic dikes occur in both types of deposits, these dikes may exhibit differences that reflect the origin of a given rock unit. Thus, those dikes in volcanic rocks deposited on the surface of tectonic denudation may have a mixture of carbonate and volcanic rock in the dike wall (figs. 4, 6-8), and the basal part of the volcanic rock may contain lenses and irregular bodies of calcibreccia (figs. 10, 21, 22).

\section{SUMMARY}

The salient points revealed by the clastic dikes are: 1. They are widely distributed within the area of the Heart Mountain fault. They are more common within the bedding-plane phase of the fault, but a few also occur in the transgressive and former land-surface phases of the fault.

2. They occur in the upper plate and in volcanic rocks that were deposited very soon after movement on the Heart Mountain fault had ceased.

3. They were intruded into the upper-plate and volcanic rocks at approximately the same time.

4. They confirm an earlier conclusion that the Heart Mountain fault movement was a cataclysmic event.

5. They were injected after movement on the Heart Mountain fault had ceased and therefore are not indicative of a fluid-flotation mechanism for the Heart Mountain fault, as suggested by Voight.

6. Injection of the dikes was caused by a rapidly increasing overburden of volcanic rocks that also rapidly increased the lithostatic pressure on the unstable fault breccia.

7. Wapiti volcanism began by rapid deposition of at least the lower part of the Wapiti over many square kilometers.

8. In some places where calcibreccia was abundant, deposition of the lower part of the Wapiti was so rapid that before the basal part was consolidated, the lithostatic pressure on it and the unstable calcibreccia became sufficient to cause both to flow upward as a dike.

9. Differences between calcibreccia dikes in indurated country rock and those in unconsolidated country rock can be used as an aid in distinguishing between volcanic rocks of the Cathedral Cliffs and Lamar River Formations that are fault emplaced by the Heart Mountain fault movement, and the Wapiti Formation that is depositional on the tectonic surface.

10. The high permeability of the extensively brecciated rocks in the lower part of the upper plate and the separation of the upper plate into numerous blocks and pieces indicate that the Heart Mountain fault movement was not aided by high pore pressure of water, air, or volcanic gas. In my opinion, the extensive brecciation of rock above the fault surface, which is observed to occur immediately above a line of seismic discontinuity separating a lower 350 -m-thick layer predominantly of shale from an upper $500-\mathrm{m}$ thick layer of carbonate rock, may well have been caused by a catastrophic earthquake of vertical acceleration approaching $1 \mathrm{~g}$. However, it remains possible that heat generated by rapid movement of the upper plate produced steam (Goguel, 1969), which helped to reduce friction on the fault.

\section{ACKNOWLEDGMENTS}

The author is indebted to R. A. Loney and W. H. Nelson for examining many thin sections of the calcibreccia. This report is based on fieldwork performed over a period of several years, and I wish to thank D. H. Anspach, W. C. Barnes, J. H. Clark, K. R. Jayne, Allan Krill, C. C. McAneny, and J. I. Ziony, who served so capably and enthusiastically as my field assistants. The suggestions and comments of R. G. Schmidt and E. B. Ekren on an earlier draft of this paper are appreciated and have been most helpful.

\section{REFERENCES CITED}

Brock, W. G., and Engelder, T., 1977, Deformation associated with the movement of the Muddy Mountain overthrust in the Buffington window, southeastern Nevada: Geological Society of America Bulletin, v. 88, no. 11, p. 1667-1677.

Bucher, W. H., 1933, Volcanic explosions and overthrusts: Transactions of the American Geophysical Union, v. 14, p. 238-242.

1940, The geology of the Cody region: Transactions of the New York Academy of Sciences, ser. 2, v. 2, no. 7, p. 1-4.

Dake, C. L., 1918, The Hart Mountain overthrust and associated structures in Park County, Wyoming: Journal of Geology, v. 26, no. 1, p. $45-55$.

Goguel, Jean, 1969, Le rôle de l'eau et de la chaleur dans les phénomènes tectoniques [The role of water and heat in tectonic phenomena]: Revue de Géographie Physique et de Géologie Dynamique, v. 11, no. 2, p. 153-163.

Hague, Arnold, 1899, Description of the Absaroka quadrangle (Crandall and Ishawooa quadrangles)[Wyoming]: U.S. Geological Survey Geologic Atlas, folio 52, 6 p.

Hewett, D. F., 1920, The Heart Mountain overthrust, Wyoming: Journal of Geology, v. 28, no. 6, p. 536-557.

Hubbert, M. K., and Rubey, W. W., 1959, Role of fluid pressure in mechanics of overthrust faulting. I. Mechanics of fluid-filled porous solids and its application to overthrust faulting: Geological Society of America Bulletin, v. 70, no. 2, p. 115-166.

Hughes, C. J., 1970, The Heart Mountain detachment fault-a volcanic phenomenon?: Journal of Geology, v. 78, no. 1, p. 107-116. 
Krill, A. G., 1976, Petrography of Heart Mountain fault breccia and fault breccia dikes and related literature review: University of California, Santa Cruz, Department of Earth Sciences, senior thesis, $46 \mathrm{p}$.

Longwell, C. R., 1922, The Muddy Mountain thrust in southeastern Nevada: Journal of Geology, v. 30, no. 1, p. 63-72.

Nelson, W. H., and Pierce, W. G., 1968, Wapiti Formation and Trout Peak trachyandesite, northwestern Wyoming: U.S. Geological Survey Bulletin 1254-H, p. H1-H11.

Nelson, W. H., Pierce, W. G., Parsons, W. H., and Brophy, G. P., 1972, Igneous activity, metamorphism, and Heart Mountain faulting at White Mountain, northwestern Wyoming: Geological Society of America Bulletin, v. 83, no. 9, p. 2607-2620.

Pierce, W. G., 1941, Heart Mountain and South Fork thrusts, Park County, Wyoming: Bulletin of the American Association of Petroleum Geologists, v. 25, no. 11, p. 2021-2045.

1957, Heart Mountain and South Fork detachment thrusts of Wyoming: Bulletin of the American Association of Petroleum Geologists, v. 41, no. 4, p. 591-626.

1960, The "break-away" point of the Heart Mountain detachment fault in northwestern Wyoming, in Short papers in the geological sciences: U.S. Geological Survey Professional Paper 400-B, p. B236-B237.

1963a, Cathedral Cliffs Formation, the early acid breccia unit of northwestern Wyoming: Geological Society of America Bulletin, v. 74, no. 1, p. 9-21.

1963b, Reef Creek detachment fault, northwestern Wyoming: Geological Society of America Bulletin, v. 74, no. 10, 1225-1236.

1968, Tectonic denudation as exemplified by the Heart Mountain fault, Wyoming, in Orogenic Belts: International Geological Congress, 23d, Prague, Czechoslovakia, 1968, Report, Section 3, Proceedings: p. 191-197.

1973a, Crandall Conglomerate, an unusual stream deposit, and its relation to Heart Mountain faulting: Geological Society of America Bulletin, v. 84, no. 8, p. 2631-2644.

$1973 \mathrm{~b}$, Principal features of the Heart Mountain fault and the mechanism problem, in De Jong, K. A., and Scholten, Robert, eds., Gravity and tectonics: New York, John Wiley and Sons, p. 457-471.

Pierce, W. G., Nelson, W. H., and Prostka, H. J., 1973, Geologic map of the Pilot Peak quadrangle, Park County, Wyoming: U.S. Geological Survey Miscellaneous Geologic Investigations Map I-816, scale $1: 62,500$.

Prostka, H. J., 1978, Heart Mountain fault and Absaroka volcanism, Wyoming and Montana, U.S.A., in Voight, Barry, ed., Rockslides and avalanches, 1-natural phenomena: New York, Elsevier, p. 423-437.

Prostka, H. J., Ruppel, E. T., and Christiansen, R. L, 1975, Geologic map of the Abiathar Peak quadrangle, Yellowstone National Park, Wyoming and Montana: U.S. Geological Survey Geologic Quadrangle Map GQ-1244, scale 1:62,500.

Smedes, H. W., and Prostka, H. J., 1972, Stratigraphic framework of the Absaroka Volcanic Supergroup in the Yellowstone National Park region: U.S. Geological Survey Professional Paper 729-C, p. C1-C33.

Stanley, R. S., and Morse, J. D., 1974, Fault zone characteristics of two well exposed overthrusts: The Muddy Mountain thrust, Nevada, and the Champlain thrust at Burlington, Vermont [abs.]: Geological Society of America Abstracts with Programs, v. 6 , no. 1, p. $78-79$.

Voight, Barry, 1973a, The mechanics of retrogressive block-gliding, with emphasis on the evolution of the Turnagain Heights landslide, Anchorage, Alaska, in De Jong, K. A., and Scholten, Robert, eds., Gravity and tectonics: New York, John Wiley and Sons, p. 97-121.

$-1973 \mathrm{~b}$, Role of fluid pressure in mechanics of South Fork, Reef Creek, and Heart Mountain rockslides [abs.]: Geological Society of American Abstracts with Programs, v. 5, no. 2, p. 233-234.

1974, Architecture and mechanics of the Heart Mountain and South Fork rockslides, in Voight, Barry, and Voight, M. A., eds., Rock mechanics: The American Northwest: University Park, Pa., Experiment Station, College of Earth and Mineral Sciences, Pennsylvania State University, p. 26-36. 